\title{
Aerobic bacterial transformation and biodegradation of dioxins: a review
}

\author{
Salametu Saibu, Sunday A. Adebusoye* (10) and Ganiyu O. Oyetibo
}

\begin{abstract}
Waste generation tends to surge in quantum as the population and living conditions grow. A group of structurally related chemicals of dibenzofurans and dibenzo-p-dioxins including their chlorinated congeners collectively known as dioxins are among the most lethal environmental pollutants formed during different anthropogenic activities. Removal of dioxins from the environment is challenging due to their persistence, recalcitrance to biodegradation, and prevalent nature. Dioxin elimination through the biological approach is considered both economically and environmentally as a better substitute to physicochemical conventional approaches. Bacterial aerobic degradation of these compounds is through two major catabolic routes: lateral and angular dioxygenation pathways. Information on the diversity of bacteria with aerobic dioxin degradation capability has accumulated over the years and efforts have been made to harness this fundamental knowledge to cleanup dioxin-polluted soils. This paper covers the previous decades and recent developments on bacterial diversity and aerobic bacterial transformation, degradation, and bioremediation of dioxins in contaminated systems.
\end{abstract}

Keywords: Dioxin, Aerobic degradation, Bacterial degradation, Sphingomonas wittichii RW1

\section{Introduction}

Industrial activities often release several pollutants (aliphatic and aromatic hydrocarbons, chlorinated aromatics, pesticides, and herbicides) into the environment as products and unwanted by-products, where they accumulate as highly toxic persistent pollutants. Among this group of chemicals are the dioxins. Dioxins, a group of structurally related chemicals, consist of dibenzo- $p$-dioxins, its 75 analogue of polychlorinated dibenzo- $p$-dioxins (PCDDs) and dibenzofurans, its 135 congeners of polychlorinated dibenzofurans (PCDFs) dictated by the numbering and positions of the chlorine atoms in the dioxin/furan molecule (Fig. 1) (Kulkarni et al. 2008). They are among the top priority chemicals of the persistent organic pollutants (POPs) popularly referred to as the "dirty dozen" due to their notable toxicity, carcinogenicity, and mutagenicity (Weber et al. 2008). From this class of substances, PCDDs and PCDFs collectively

\footnotetext{
*Correspondence: sadebusoye@yahoo.com; sadebusoye@unilag.edu.ng Faculty of Science, Department of Microbiology, University of Lagos, Akoka, Lagos, Nigeria
}

referred to as PCDD/Fs are of serious health and environmental concern owing to their toxicity, environmental persistence, and bioaccumulation in biota (Ghimpetxeanu et al. 2014; Squadrone et al. 2015). They are mainly produced unintentionally during synthesis of haloaromatic compounds, bleaching of pulp, recycling of metals, and incineration of chlorine-containing organic materials, and domestic and industrial wastes (Klees et al. 2015, Tue et al. 2016). They are also produced naturally though, to a minimal extent during volcanic eruption and natural forest fires (Hoekstra et al. 1999). In addition, Hoekstra et al. (1999) unambiguously showed that nearly 20 congeners of PCDD/F were naturally produced in Douglas fir forest soil through a mechanism involving congeners of chlorophenol in a reaction probably mediated by peroxidases. In opposition to other compounds of serious ecological problem like polychlorinated biphenyls (PCBs) and polychlorinated pesticides (pentachlorophenol, gammahexachlorocyclohexane, or lindane), dioxins were unintentionally produced. Unfortunately, owing to their chemical and thermal stability, recalcitrance to 

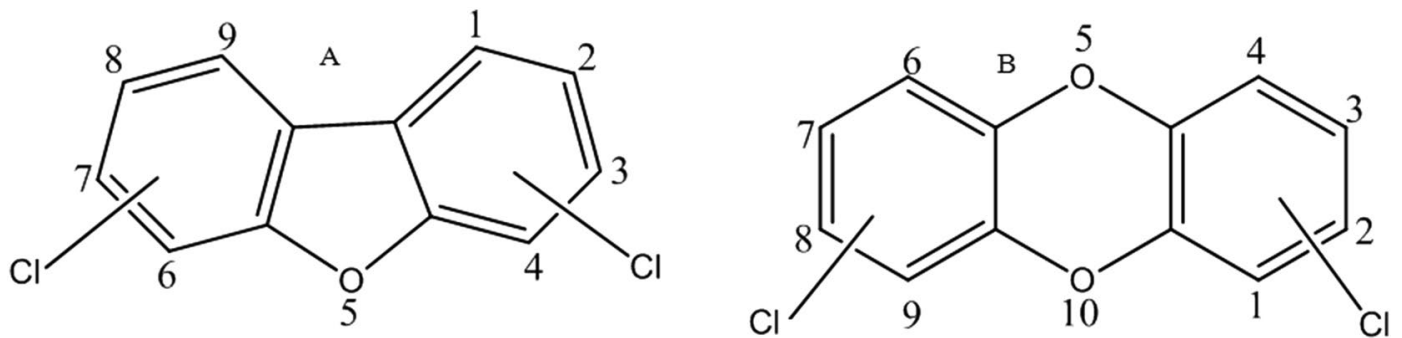

Fig. 1 General structures of dibenzofurans (a) and dibenzo-p-dioxins (b). The numbering refers to carbon atom available for chlorine substitution

microbial degradation, and toxicity to the biota, they are one of the most controversial environmental contaminants (Kaiser 2000). They are tightly adsorbed onto organic matters and mineral surfaces in soils and sediments because of their high hydrophobicity (Rose 2014). A huge amount of very toxic dioxin congeners was released into the environment during the Vietnam War and Seveo industrial accident (Hay 1977; Hay 1978; Bertazzi et al. 1998). Their global distribution, potential for toxic and carcinogenic effects on human and wildlife populations, and proven bioaccumulation properties demonstrate them to be of environmental health concern and ecological effect (Consonni et al. 2008). All these have led to various attempts to find lasting solutions and subsequent detoxification and degradation processes for polluted systems.

Remediation of PCDD/Fs-contaminated sites through physical and chemical approaches is very costly. Dioxins' chemical inertness makes the removal of these pollutants very challenging in environmental technology (Kulkarni et al. 2008). Series of physicochemical processes like photodegradation, thermal remediation, dechlorination with metal catalysts, and dioxin inhibitors such as nitrogen and sulfur compounds in dioxin contaminated waste have been considered for application of dioxin detoxification and degradation (Lin et al. 2015; Liu et al. 2015; Palanisami et al. 2015). However, these technologies are not economically and ecologically reasonable to remedy sizeable areas of polluted soils. Thermal remediation, for instance, is difficult to apply for mediums that are not easily burnt, like sediments (Bedard 2008). More often than not these methodologies end up introducing new chemical wastes into the environment. Therefore, biological approaches of harnessing microorganisms to remove toxic and recalcitrant compounds from the environment have become more popular and acceptable as an alternative owing to its economic feasibility as well as minimal impact on the environment (Chang 2008; Jeon et al. 2016). For effective clean-up of these matrices, bioremediation is touted as a promising technology due to its cost effectiveness compared to conventional approaches as well as its environmental compatibility and flexibility (Vidali 2001; Chen et al. 2016).

Microorganisms, which are ubiquitously distributed in sediments, soils, and water bodies, are significant agents in the total decomposition of organic compounds and recycling of global carbon, and cannot be overemphasized as a cost-effective and sustainable approach to detoxify the environment of dioxins (Vidali 2001). In this regard, non-chlorinated dibenzofuran (DF) has served as a blueprint chemical in biological degradation studies of PCDD/Fs. Some bacterial strains have been shown to degrade DF and/or non-substituted dibenzo- $p$-dioxin (DD) and some lightly substituted congeners, including Sphingomonas sp. HH69 and Sphingomonas wittichii RW1 (Fortnagel et al. 1990; Wittich et al. 1992; Wilkes et al. 1996). Others are Nocardioides aromaticivorans (Kubota et al. 2005), Terrabacter sp. strain DPO360 (Gai et al. 2007), Rhodococcus sp. HA01 (Aly et al. 2008), Pseudomonas putida B6-2 (Li et al. 2009), Pseudomonas sp. strain ISTDF1 (Jaiswal et al. 2011), Rhodococcus sp. strain p52 (Peng et al. 2013), Pseudomonas mendocina strain NSYSU (Lin et al. 2014), and Agrobacterium sp. PH-08 (Le et al. 2014), Among the listed organisms, Pseudomonas sp. strain CA10 (Sato et al. 1997) and strain RW1 (Nam et al. 2006) were extensively studied with regards to the genes coding for the dioxin catabolic routes, and also as potential candidates for remediation of contaminated soils. However, most aerobic degradation studies are limited to less dangerous dioxin congeners with up to three chlorine substituents (Chen et al. 2014). Studies pertaining to degradation of highly substituted congeners are relatively scarce. To this end, there is need to source and develop more bacterial strains with unique metabolic potentials which can be applied for effective remediation in dioxin-polluted sites as well as using powerful molecular tools to detect large-scale bacterial populations from polluted unexplored environments (everything is everywhere but 
environment selects owing to different climatic conditions) should also be considered too. In this communication, we give a summary on the latest knowledge and developments in aerobic bacterial degradation and transformation of dioxins and their possible bioremediation candidacies for cleanup of polluted soil systems.

\section{Bacterial transformation and degradation of dioxins}

Generally, microorganisms are essential in the environment for the degradation and mineralization of organic compounds. They transform these pollutants into less toxic compounds (metabolites or intermediates) with the abetment of microbial enzymes. Microorganisms can mineralize an organic compound which is being used as the sole carbon and energy source, or they use alternative sources of carbon and energy and the biotransformation of these pollutants occurs as a parallel activity (co-metabolism). Products of these catabolic reactions can be further mineralized and then channeled into the biogeochemical cycle, because incomplete degradation can lead to formation and build-up of more toxic metabolites than its primary substrates in most cases. This can also result in shutdown of the degradation pathway of the compound (Kao et al. 2001).

Extensive studies have been done on bacterial isolates and/or bacterial communities that can degrade PCDD/Fs in the environment. Diverse microorganisms are capable of degrading non-substituted dioxins (DD/F), but very few have the capacity of the aerobic degradation of highly chlorinated congeners (tetra- to octachlorinated) because of the increased stability chlorination adds to the carbon skeleton (Hong et al. 2002, 2004).

Microorganisms isolated by several workers with ability to degrade persistent organic compounds have so far shown encouraging results for subsequent use in bioremediation technologies (Halden et al. 1999; Habe et al. 2002; Nam et al. 2008). From historical perspective, studies on microbial degradation of PCDD/Fs started in the 1970s (Kearny et al. 1972; Matsumura and Benezet 1973) where microorganisms indigenous to soils spiked with 2,3,7,8-tetrachlorodibenzo-p-dioxin (2,37,8-TCDD) could barely degrade $60 \%$ of $100 \mathrm{ppm}$ of the congener after $350 \mathrm{~d}$ of incubation, even though other dichlorinated congeners were effectively utilized in $70 \mathrm{~d}$. It was a general belief that $\mathrm{PCDD} / \mathrm{Fs}$ are refractory to microbial degradation.

The use of microorganisms in soil, water, and sediment detoxification processes requires a deeper knowledge of the important catabolic routes and critical reactions and also factors affecting their efficiency and subsequent optimization schemes to overcome critical metabolic steps. A number of studies have suggested some bacterial species able to metabolize $\mathrm{DD} / \mathrm{F}$ and, in some cases, its chlorinated analogues as well as the application of some microorganisms as bioremediation candidates. Biochemical, molecular, and bioengineering facets of the microbial degradation of dioxin compounds have been reviewed (Chang 2008; Wittich 1998; Hiraishi 2003).

Microbial reductive dechlorination is the dominant metabolic process in anaerobic environments. This is quite interesting due to its spectacular catabolic potential against highly chlorinated congeners. This activity was first indicated by changes in the dioxin congener patterns as well as build-up of lightly chlorinated analogues in anaerobic environments (Townsend 1983). Anaerobic microbial community was implicated in the reductive dehalogenation of highly chlorinated PCDD/Fs in contaminated sediments, sludges, and soils (Barkovskii and Adriaens 1996; Yoshida et al. 2005). However, microbial dechlorination of highly chlorinated analogues produces most toxic congeners, i.e., 2,3,7,8-TCDD as an intermediate due to deletion of chlorine at positions 1, 4, 6 and/ or 9 (Barkovskii and Adriaens 1996). Several species of Dehalococcoides are known to dechlorinate PCDDs. Chloroethene dechlorinator, "Dehalococcoides ethenogens strain 195 has the ability to dechlorinate certain PCDD analogues (Fennell et al. 2004). Similarly, Dehalococcoides sp. strain CBDB1 known to degrade chlorobenzene was also reported to reductively dechlorinate selected PCDD congeners (Bunge et al. 2003). It is noteworthy that this strain dechlorinated the environmentally significant congeners 1,2,3,4-TCDD and 1,2,3,7,8-pentachlorodibenzo-p-dioxin (1,2,3,7,8-PeCDD) to less-chlorinated congeners. In addition, molecular analysis has shown that the organism contained several reductive dehalogenase (RDH) genes (Holscher et al. 2004).

A promising biodegradation approach for effective destruction of PCDD/Fs in environmental matrices may consist of sequential anaerobic and aerobic metabolic processes. Consequently, anaerobic-aerobic process is recommended as a prospective bioremediation scheme for cleanup of environments polluted with halogenated compounds such as PCBs, PCDD/Fs, and pesticides (Adebusoye et al. 2008; Bedard 2008; Gioia et al. 2014; Lin et al. 2014). In this scenario, an initial reductive dehalogenation step would result in production of lightly chlorinated congeners from highly substituted ones. This is followed by degradation and assimilation of the aromatic carbon skeleton of the reductive dechlorination products in aerobic process resulting in final mineralization of the compound. However, some studies have revealed the biodegradation of PCDD/Fs (near fully chlorinated DD/DF) in polluted environments through biostimulation and bioaugmentation (single isolate and microbial consortia) under aerobic conditions without accumulation of toxic 
substituted congeners (Nam et al. 2008; Chen et al. 2013; Chen et al. 2016; Lin et al. 2017).

\section{Aerobic bacterial degradation of dioxins}

In aerobic conditions, microorganisms degrade dioxins and their substituted analogues by hydroxylation and cleavage of aromatic nucleus through oxidative degradation. There are two main processes of initial oxidation of dioxin namely: lateral dioxygenation and angular dioxygenation. In lateral dioxygenation, hydroxylation of the aromatic ring occurs on carbon atoms 1,2 or 2,3 or 3,4 which is similar to previously described pathways for degradation of other aromatic compounds like biphenyl, naphthalene, and polycyclic aromatic hydrocarbons (PAHs). In the case of angular dioxygenation, it occurs at carbon atoms vicinal to the ether bridge $(4,4 a)$, which basically results in the outright destruction of the planar structure and consequently leading to the drastic reduction of the compound toxicity (Wittich 1998). The dioxygenases have a wide range of substrates specificity and belong to the Rieske non-heme iron oxygenases. A few reports have implicated bacteria in the degradation of DF through both dioxygenation pathways (Yamazoe et al. 2004; Le et al. 2014).

\section{Lateral dioxygenation}

The first reaction in aerobic bacterial degradation of aromatic compounds involves the addition of two hydroxyl groups at the lateral position of the benzene ring, with consequent production of cis-dihydrodiols (Figs. 2 and 3) which is analogous to other aromatic catabolic pathways (PCBs, naphthalene, carbazole, etc.). A characteristic feature of this kind of degradation pathway is the generation of a yellow-colored metabolite identified as the enol of 2-hydroxy-4-( $3^{\prime}$ oxo- $3^{\prime} \mathrm{H}$-benzofuran-2'-yliden) but-2-enoic acid (HOBB). The enzymes that catalyze the incorporation of molecular oxygen into aromatic nuclei are called dioxygenases. Catechol is formed during dehydrogenation of cis-dihydrodiols by cis-dihydrodiol dehydrogenase which is a critical reaction in the catabolic pathways of aromatic compounds (Seo et al. 2009).

However, some bacteria strains have been shown to degrade the compound laterally using other aromatic compounds (biphenyl or naphthalene) as the principal carbon source cometabolically (Becher et al. 2000; Mohammadi and Sylvestre 2009; Li et al. 2009) producing HOBB as the final product. Interestingly, Pseudomonas putida strain B6-2 has been shown to degrade HOBB through salicylic acid when grown with biphenyl (Li et al. 2009). Recently, Ali et al. (2019) reported a novel dioxygenase designated HZ6359 from Pseudomonas aeruginosa FA-HZ1 which was amplified and expressed successfully in $E$. coli. The enzyme was found to belong to a family of lateral dioxygenases which was able to oxidize DF to 1,2-dihydroxy-1,2-dihydrodibenzofuran as a metabolic product. In addition, the dioxygenase could also oxidize halogenated analogues including 2,8-dibromoDF and 4-(4-bromophenyl)DF. Although the authors claimed that strain FA-HZ1 could also metabolize DF by angular dioxygenation, but such could not be substantiated by the available data.

\section{Angular dioxygenation}

This reaction is mediated by the Rieske non-heme iron oxygenases, referred to as angular dioxygenases, which occur at angular positions $(4,4 \mathrm{a}$ or $1,10 \mathrm{a})$ vicinal to the ether bridge (Figs. 2 and 3) of DF or DD with subsequent production of hemiacetal (unstable), spontaneous cleavage, and rearomatization of the hemiacetal produces 2,2',3-trihydroxybiphenyl (TrHB) or 2,2'3-trihydroxydiphenyl ether (TrHDE), respectively (Xu et al. 2006). The dihydroxylated rings of TrHB and TrHDE through an extradiol dioxygenase (TrHB dioxygenase) is then metacleaved. Hydrolysis (hydrolase) of the meta-cleavage products yields catechol and salicylic acid from DD and DF respectively (Wittich et al. 1992; Wilkes et al. 1996; Hong et al. 2004). Additionally, in the case of PCDF, metabolism sometimes results in the production of 2-methyl-4H-chroman-4-ones particularly when the substrate in question has chlorine substituents on both rings (Field and Sierra-Alvarez 2008). The angular pathway is more important than lateral dioxygenation in decontamination of dioxin, because this single-step oxygenation knocks down the planar structure of dioxin and, consequently, reduces its toxicity (constructive pathway).

Generally, three dioxygenases are recognized to catalyze the initial reaction of the dioxin catabolic pathway namely; DF 4,4a-dioxygenase ( $d b f A$ or $d f d A$ ) characterized from Terrabacter sp. strain DBF63, DD 1,10a-dioxygenase $(d x n A)$ obtained from Sphingomonas sp. strain RW1 as well as Rhodococcus sp. strain HA01 and carbazole 1,9a-dioxygenase (carAa) from Pseudomonas sp. strain CA10 all of which attack at the angular position (Field and Sierra-Alvarez 2008). According to Aly et al. (2008), expression of both $d f d A$ and $d b f A$ genes was observed during growth of strain HA01 on DF. However, revelation from the heterologous expression of both oxygenase systems confirms their involvement in angular oxygenation of DF and DD; they, nevertheless, demonstrated differential substrate specificity with regards to congeners of PCDF transformed. Expansion of studies on bacterial metabolism of dioxins has further uncovered additional dioxygenases. For instance, a $d f d A 1 A 2 A 3 A 4$ gene cluster coding for a ring hydroxylating dioxygenase was detected in Nocardioides sp. DF412 (Miyauchi et al. 2008; Sukda et al. 2009). Surprisingly, these genes 
<smiles>c1ccc2c(c1)oc1ccccc12</smiles><smiles></smiles>

\section{Dibenzofuran}

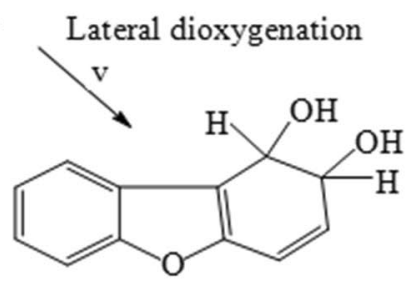

\section{1,2-Dihydroxy-1,2-dihydrodibenzofuran}

4,4a-Dihydroxy-4-hydrodibenzofuran<smiles>Oc1ccccc1-c1cccc(O)c1O</smiles>

2,2,3-Trihydroxybiphenyl<smiles>Oc1ccc2oc3ccccc3c2c1O</smiles>

1,2-Dihydroxydibenzofuran

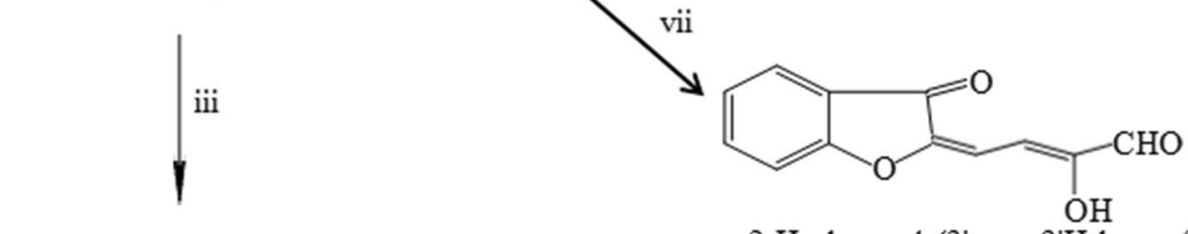<smiles>O=C(O)C1C=CC=C(c2ccccc2O)C1=O</smiles>

6-Hydroxy-6-(2'hydroxyphenyl)-2oxohexa-3,5-dienoic acid

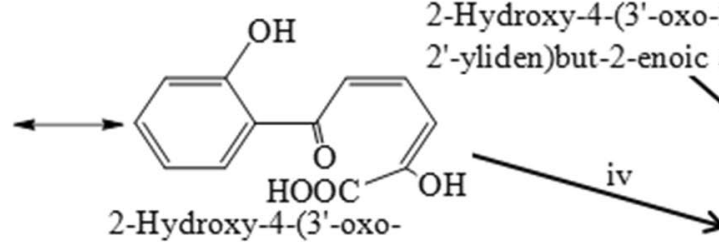
3'H-benzo furan-2' yliden)but-2-enoic acid

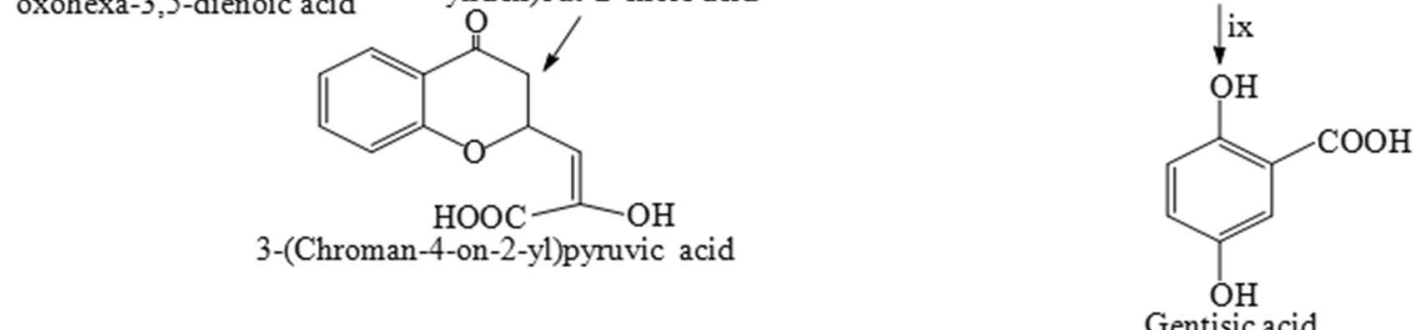

3-(Chroman-4-on-2-yl)pyruvic acid

$\mathrm{OH}$

Fig. 2 Pathways for metabolism of dibenzofuran through angular and lateral dioxygenation by Janibacter terrae strain XJ-1 as proposed by Jin et al. (2006) with slight modification. Dibenzofuran-4,4a-dioxygenase (i), 4,4a-dihydroxy-4-hydro-dibenzofuran dehydrogenase (ii), 2,2',3-trihydroxybiphenyl dioxygenase (iii), 2-hydroxy-6-oxo-6-(2'-hydroxyphenyl)-hexa-2,4-dienoic acid hydrolase (iv), dibenzofuran-1,2-dioxygenase (v), 1,2-dihydroxy-1,2-dihydrodibenzofuran dehydrogenase (vi), 1,2-dihydroxydibenzofuran dioxygenase (vii), 2-hydroxy-4-(3'OxO-3'H-benzofuran-2' yliden)but-2-enoic acid hydrolase (viii), and salicylic acid-5-hydroxylase (ix)

were located on a plasmid, whereas the $d f d B C$ gene cluster coding for other enzymes downstream of the $d f d A$ genes was found on the chromosome. The $b p h A$ genes encoding the biphenyl dioxygenase, is among the most extensively studied dioxygenases that has been demonstrated to catalyze the stereospecific oxygenation of many heterocyclic aromatics including biphenyl, DF and DD.

The BphA proteins are actually famous for catalytic dihydroxylation of biphenyl and many PCB congeners, but some have been reported to catalyze dioxins even 


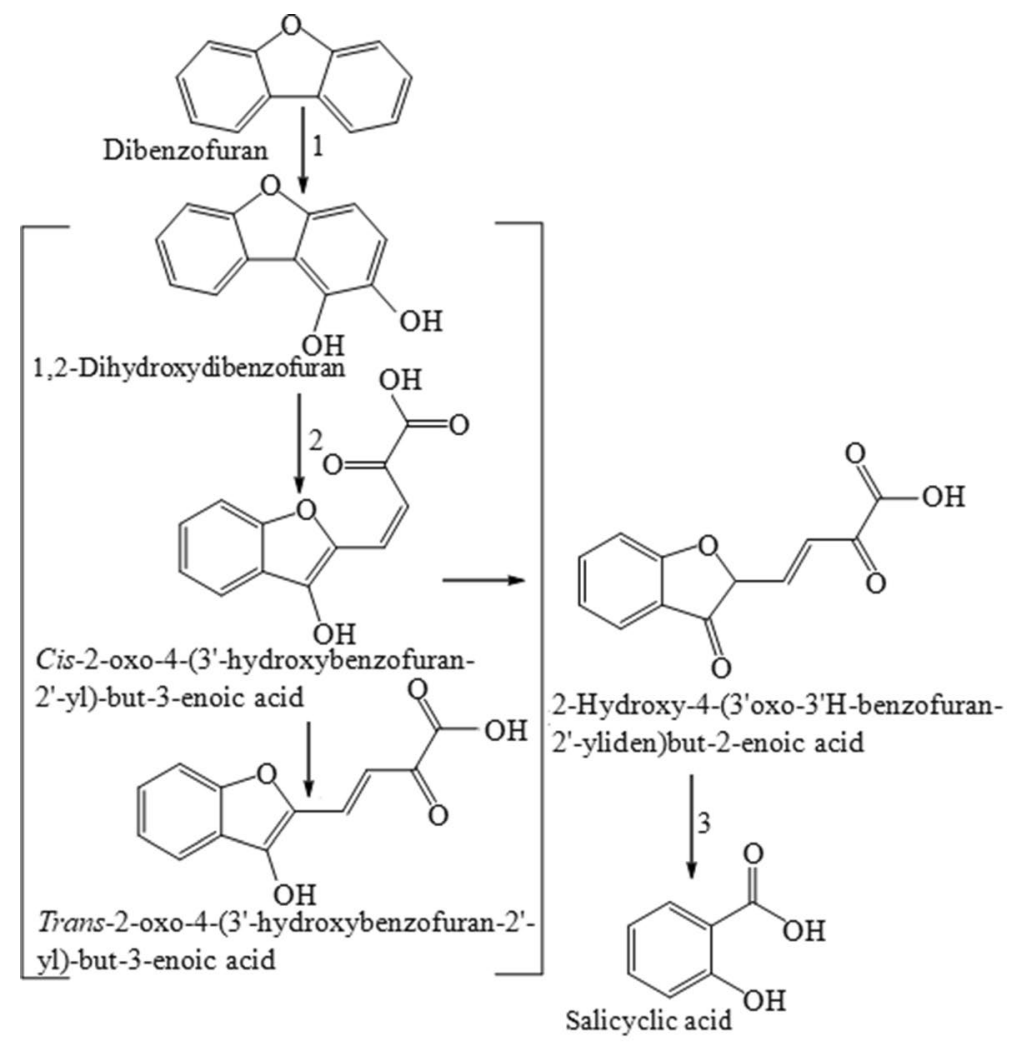<smiles>c1ccc2c(c1)Oc1ccccc1O2</smiles><smiles>OC1C=CC=C2Oc3ccccc3OC21</smiles>

1,10a-dihydroxy-1hydrodibenzo-p-dioxin<smiles>Oc1ccccc1Oc1cccc(O)c1O</smiles>

2,2,3-Trihydroxydihpenyl<smiles>CCCOC(=O)/C=C\C=C(\C)Oc1ccccc1O</smiles>

2-hydroxy-6-oxo-6-(2-hydroxyphenyl)hexa-2,4-dienoic acid

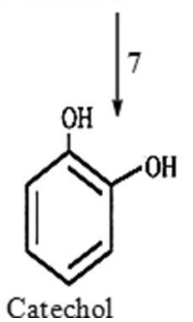

Fig. 3 Lateral and angular dioxygenation pathway for metabolism of dibenzofuran and dibenzo-p-dioxin, respectively, from the proposed scheme of Becher et al. (2000) and Field and Sierra-Alvarez (2008). Product in parenthesis undergoes spontaneous transformation due to its instability. Dibenzofuran-1,2-dioxygenase (1), 1,2-dihydroxybenzofuran dioxygenase (2), 2-hydroxy-4-(3'-oxo-3'H-benzofuran-2'yliden(but-2-enoic acid hydrolase (3), dibenzo-p-dioxin-1,10a-dioxygenase (4), 1,10a-dihydroxy-1-hydrodibenzo-p-dioxin dehydrogenase (5), 2,2',3-trihydroxydiphenyl ether dioxygenase (6), and 2-hydroxy-6-oxo-6-(2-hydroxyphenoxy)-hexa-2,4-dienoic acid hydrolase (7)

though poorly. Previously, Seeger et al. (2001) unequivocally demonstrated the angular dioxygenation of DD by the bphA-encoded biphenyl dioxygenase of Burkholderia xenovorans strain LB400. In contrast, this multifunction enzyme laterally oxygenates DF resulting in the production of dihydrodiols. By implication, this enzyme has the ability to hydroxylate ortho or angular carbons carrying a range of substituents which exercise electron-withdrawing inductive effects. In a related study, Iwasaki et al. (2007) also showed that the bphA genes of Rhodococccus sp. RHA1 encoded a biphenyl dioxygenase capable of transforming DF conveniently through both angular and lateral dioxygenation whereas, DD was converted solely though angular dioxygenation. In an 
attempt at expanding the catalytic activity of the $b p h A$ dioxygenases, a variant of strain LB400 bphA dioxygenase obtained by site-directed mutagenesis was found to have improved substrate spectrum by acquisition of novel and multifunctional degradation capabilities including enhanced catalytic activity toward DF (Mohammadi et al. 2011; Kumar et al. 2012). This mutant metabolizes DF and 2-chlorodibenzofuran (2-CDF) proficiently more than the wild type. But quite interestingly, the regiospecificity of this variant toward both substrates varies. While DF was primarily metabolized through a lateral dioxygenation, 2-CDF was essentially metabolized through the angular route.

A new angular dioxygenase gene cluster pbaA1A2B whose products shared $65 \%, 52 \%$, and $10 \%$ identity with the corresponding $\alpha$ and $\beta$ subunits and the ferredoxin component of dioxin dioxygenase from strain RW1, respectively, was found in the draft genome of Sphingobium wenxiniae JZ-1 (Wang et al. 2014). The gene cluster codes for phenoxybenzoic acid $1^{\prime}, 2^{\prime}$-dioxygenase thus enabling the organism to metabolize 3-phenoxybenzoic acid. Since strain JZ-1 was unable to utilize DD and $\mathrm{DF}$, the connection of this dioxygenase with PCDD/Fs metabolism is yet to be established.

\section{Enzymes involved in the upper pathway of dioxin degradation}

Generally, the first step in the oxidative degradation of aromatic compounds to form dihydroxylated intermediates is mediated by monooxygenases or hydroxylating dioxygenases as shown above. Aromatic ring hydroxylating dioxygenases belonging to the Rieske non-heme iron oxygenases are enzyme systems that are multicomponent in nature. On the basis of their sequences, these dioxygenases are classified into four groups namely; I, II, III, and IV. Group I consists of homo-multimer oxygenases, while the remaining groups contained heterodimer oxygenases. Benzoate/toluate dioxygenases are for group II, naphthalene/polycyclic aromatic hydrocarbon dioxygenases for group III, while group IV is for benzene/toluene/biphenyl dioxygenases (Nam et al. 2001).

The bacterial degradation pathway of dioxins has been elucidated in terms of the enzymes involved in several bacteria, but the most studied is strain RW1. The enzymes consist of the multicomponent dioxygenase, meta-cleavage enzymes, and the hydrolytic enzymes (Fig. 2). The initial reaction (angular dioxygenation) is catalyzed by a multicomponent complex dioxygenase which initiates the oxidation of the dioxin molecule by the addition of molecular oxygen (Fig. 4). The dioxygenase consists of terminal hydroxylating dioxygenase (dxnA1-large sub unit and dxnA2-small sub unit) and the electron transfer system (two reductases-a flavoprotein reductase, $\operatorname{red} A 2$, and ferredoxin, $f d x 1$ ) (Armengaud et al. 1998). A putidaredoxin-type ferridoxon is utilized in the electron transport system as against the usual Riesketype ferredoxin. To hydroxylate the dioxin compound, the dioxygenase requires dioxygen and electrons. During oxidation of NADH, the electrons are supplied and the flavoprotein reductase mediates the transference of electron to the terminal oxygenase from NADH through the ferredoxin. The multicomponent dioxygenase system of strain RW1 is a three-component hydroxylating dioxygenase system for aromatics, although the reductase of strain RW1 lacks a Fe-S cluster from those of group I and III. Therefore, the dioxin dioxygenase system of strain RW1 is grouped into class IIA of the aromatic ring-activating dioxygenases. The genes encoding the initial angular dioxygenase ( $\mathrm{dxnA} 1$ and $\mathrm{dxnA2}$ ) and the electron transfer component of the dioxygenases ( $\mathrm{fdx} 1$ and redA2) are not clustered on an operon system but located in distinct and separate genome segments. This indicates that the bacterium might have picked up the genes from other organisms, or the dioxin metabolic apparatus according to Nojiri et al. (2001) is evolving.

The second enzyme in the dioxin catabolic pathway is 2,2',3-trihydroxybiphenyl (2,2',3-THB)-1,2-dioxygenase, an extradiol (meta-cleavage) dioxygenase. This enzyme converts $2,2^{\prime}, 3$-THB to 2-hydroxy-6-oxo-6-(2'hydroxyphenyl)-hexa-2,4-dienoic acid (HOHPDA). The enzyme is a monomeric protein, relatively small in size $(32 \mathrm{kDa})$ and oxygen labile. The primary structure of this enzyme has a high homology with 2,3-dihydroxy-1,2-dioxygenases from biphenyl-degrading strains because of the structural relatedness of the two substrates. Four histidines, one tyrosine, and one glutamate of the amino acid residues have been shown to function as endogenous ligands to the iron component of the extradiol dioxygenases. The final step in the upper metabolic pathway of DF involves the hydrolytic cleavage of the $\mathrm{C}-\mathrm{C}$ bonds of HOHPDA to yield salicylate, a reaction mediated by HOHPDA hydrolase. Bunz and Cook (1993) demonstrated that strain RW1 possessed two isofunctional hydrolases with both showing $50 \%$ homology from the $\mathrm{N}$-terminal of their amino acid sequences. Each enzyme is responsible for the hydrolytic catalysis of HOHPDA and 2-hydroxy-6-oxo-6-phenylhexa-2,4-dienoic acid (HOPDA) and are essentially constitutively expressed by the organism.

\section{Metabolic repertoire of Sphingomonas wittichii strain RW1}

Substantial research has been done on the metabolic functionalities of Sphingomonas wittichii strain RW1 with respect to degradation of array of dioxin congeners. This strain is considered to be the best characterized 


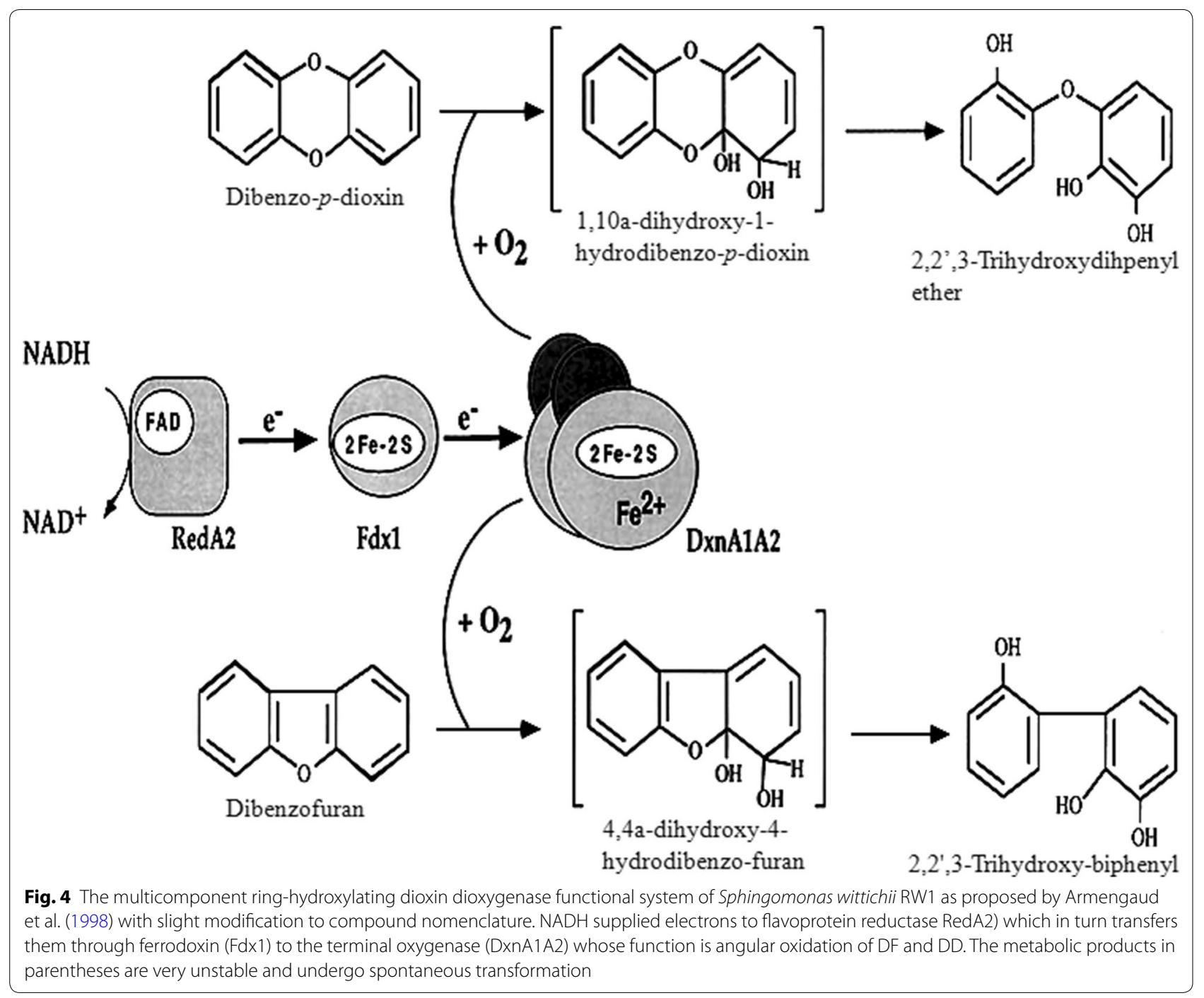

among organisms with dioxin degradation capability (Nojiri and Omori 2002). It was isolated from Elbe River (Germany) through enrichment culture technique and grows within the mesophilic temperature range $\left(30{ }^{\circ} \mathrm{C}\right)$ (Wittich et al. 1992). It belongs to the Alphaproteobacteria class which assimilates L-arabinose, D-mannitol, maltose, and phenyl-acetic acid. The microorganism grew on both DD and DF as the sole source of carbon and energy. Wilkes et al. (1996) showed the ability of RW1 to oxidize some PCDD/F congeners. The bacterium degraded quite a number of mono- and dichlorinated DFs and DDs, but failed to degrade the highly chlorinated analogues. 2-chlorodibenzofuran (2-CDF) and 3-CDF were degraded to their corresponding chlorinated salicylic acids which is an evidence of dioxygenation of the aromatic nuclei at the angular position. However, in the case of 4-CDF and 2,3-dichlorodibenzofuran (2,3DCDF) used as substrate for resting cells, metabolites 3-chloro- and 4,5-dichlorosalicylic acids, respectively, were identified. The non-detection of salicylic acid during 4-CDF incubation and accumulation of 3-chlorosalicylic acid in the culture fluid suggested the lack of dioxygenation of the substituted aromatic ring. 4,5-dichlorosalicylic acid recovery was also nearly stoichiometric thus indicating that the growth of the organism occurred at the expense of the non-substituted ring. The absence of dioxygenation on the chlorinated ring of 2,3-DCDF may be due to steric hindrance or electronic influences by the chlorine substituents on the same aromatic ring. Alternatively, salicylic acid may have been entirely consumed by the resting cells, consequently preventing the detection of this metabolite. Also, no metabolites were detected during the incubation of RW1 resting cells with 3,7-DCDF and 2,4,8-trichlorodibenzofuran (2,4,8$\operatorname{TrCDF})$ in the culture supernatants. It remained unclear whether the recalcitrance was due to electronic effects 
or steric hindrance caused by the heftiness of the chlorine substituents. Similar results were obtained when the resting cells pre-grown on DF were incubated with the PCDD congeners. In a related study by Hong et al. (2002), DF-grown resting cells of RW1 was used to aerobically transform 2,7-DCDD and 1,2,3,4-TCDD. Fortyseven percent of 2,7-DCDD was biotransformed to 4-chlorocatechol after $120 \mathrm{~h}$ incubation. During 1,2,3,4TCDD incubation; however, $37 \%$ of the congener was transformed. Examination of the entire culture fluid showed two metabolites (3,4,5,6-tetrachlorocatechol and 2-methoxy-3,4,5,6-tetrachlorophenol) accumulated. About $37 \%$ of 1,2,3,4-TCDD had been transformed to $3,4,5,6$-tetrachlorocatechol, while $6 \%$ was converted to 2-methoxy-3,4,5,6-tetrachlorophenol.

In spite of the pronounced recalcitrance of highly chlorinated congeners of dioxin, Nam et al. (2006) unequivocally demonstrated for the first time, transformation of 1,2,3,7,8-PeCDD and 1,2,3,4,7,8-hexachlorodibenzop-dioxin (1,2,3,4,7,8-HeCDD) by $S$. wittichii strain RW1. Interestingly, both compounds are not only ubiquitous pollutants, they are known to have long half-lives when compared to lightly substituted analogues (McLachlan et al. 1996). According to Nam et al. (2006), nearly $100 \%$ of the initially supplied $1,2,3,4,7,8-\mathrm{HeCDD}$ was transformed through 2,2',3-trihydroxy-hexachlorodiphenyl ether (produced in trace amounts) to 3,4,5,6-tetrachlorocatechol and 2-methoxy-3,4,5,6-tetrachlorophenol as major metabolites. Quite surprisingly, 1,2,3,7,8-PeCDD which is less chlorinated was not transformed to any detectable extent. Similarly too, 1,2,3-TrCDD was transformed through 2,2',3-trihydroxy-1,2,3-trichlorodiphenyl ether to 3,4,5-trichlorocatechol, whereas, 2,3,7-trichlorodibenzo- $p$-dioxin (2,3,7-TrCDD) was not metabolized. The dynamics of dioxin transformation in strain RW1 readily suggests that chlorine substitution patterns on the dioxin ring influences biodegradability rather than the overall number of chlorine substituents. Identification of the metabolites extracted from the culture fluid further implied a dioxygenase attack on the less substituted aromatic ring, as depicted in Fig. 5.

In a different study, Bunz and Cook (1993) purified and characterized angular dioxygenase enzyme system from strain RW1 and called it a three-component ring hydroxylating dioxygenase, designated DF 4,4a-dioxygenase system. The enzyme needs the involvement of a flavoprotein, reductase $\mathrm{A} 2$, and an iron-sulfur protein to which is involved in the movement of electrons from NADH to the dioxygenase for activation of oxygen which consists of terminal oxidase $d x n A 1$, a reductase $(\operatorname{Red} A 2)$, and a ferredoxin as revealed in Fig. 4.

Genes coding for each component in the catabolic routes have been cloned, sequenced, and expressed
(Armengaud et al. 1998). Gene-encoding enzymes involved in DD and DF degradation $(d x n A 1, d x n A 2, f d x 1$, and $\operatorname{red} A 2)$ are dispersed over the entire chromosome. Likewise, genes responsible for the upper pathway have also been elucidated, cloned, and expressed in E. coli. The authors suggested that the genes are likely participants in oxidation of DF and DD.

The complete genome sequencing of RW1 gave indepth view on improved studies of its peculiar metabolic competence and the precise locations of the gene sequences of interest. The RW1 genome comprises of two mega plasmids and one chromosome (Miller et al. 2010). The RW1 genome has multiple TonBdependent outer membrane receptor protein genes which reside within the operons and was suspected to code for enzymes taking part in aromatic hydrocarbon catabolism.

Strain $R W 1$ response to changes in water stress conditions through evolving adaptation which is important for successful application in soil bioremediation strategy was a subject of investigation through the genomewide expression of the organism in response to induced water stress condition. In addition, the bacterium was perturbed with either non-permeating solute or cellpermeating solute. The responses to the different stress conditions were assessed and compared using membrane fatty acid analyses, growth assays, and transcriptome profiling. The results showed that both the non-permeating and permeating solutes triggered divergent adaptive responses, indicating that the solutes affect cells in major disparate ways (Johnson et al. 2011). Cellular responses of RW1 during DF metabolism were monitored during gene transcription (genome-wide level). Several unessential and related aromatic pathways were proposed as well as high-expression level of non-catabolic genes during the initial exposure to DF (stressor), However, with continuous exposure, DF was perceived as a carbon source and metabolized through various pathways in parallel (Coronado et al. 2012).

In a related study, a genome-wide transposon scanning of the bacterium was investigated to have a perception on the survival ability of RW1 in a stressed environment (Roggo et al. 2013). It also identified putative functions necessary for survival in soil during drought condition. To this extent, RW1 transposon libraries were generated and grown in liquid medium-containing salicylic acid as exclusive carbon and energy source either in the presence or absence of salt stress conditions. On the other hand, libraries were grown in moist sand with salicylic acid. On analysis, no transposon reads were recovered in $10 \%$ of the annotated genes of RW1 genome amounting to a total of 579 genes in any of the libraries under any of the growth conditions, thus, indicating those to 
<smiles>Clc1cc2c(c(Cl)c1Cl)Oc1ccccc1O2</smiles>

1,2,3-Trichlorodibenzo-p-dioxin<smiles>OC1C=CC=C2Oc3c(cc(Cl)c(Cl)c3Cl)OC21O</smiles>

1,10a-dihydroxy-1-hydrotrichlorodibenzo-p-dioxin<smiles>Oc1cccc(Oc2c(O)cc(Cl)c(Cl)c2Cl)c1O</smiles>

2,2',3-Trihydroxy-trichlorodiphenyl ether<smiles>CC=C[Al]c1c(O)cc(Cl)c(Cl)c1Cl</smiles>

3,4,5-trichlorocatechol<smiles>[2H]c1c(Cl)c(Cl)c(Cl)c2c1Oc1cc(Cl)c(Cl)cc1O2</smiles>

1,2,3,4,7,8-Hexachlorodibenzo-p-dioxin<smiles>Cc1c(Cl)c(Cl)c(Cl)c2c1OC1=CC(Cl)=C(Cl)[C@H](O)[C@]1(O)O2</smiles>

1,10a-dihydroxy-1-hydro-

hexachlorodibenzo-p-dioxin<smiles>Oc1c(Oc2c(O)c(Cl)c(Cl)c(Cl)c2Cl)cc(Cl)c(Cl)c1O</smiles>

2,2,3-Trihydroxy-hexachlorodiphenyl ether<smiles>CC=C[Al]c1c(O)c(O)c(Cl)c(Cl)c1Cl</smiles>

3,4,5,6-tetrachlorocatechol<smiles>COc1c(O)c(Cl)c(Cl)c(Cl)c1Cl</smiles>

2-methoxy-3,4,5,6-

tetrachlorophenol

Fig. 5 Pathways for biotransformation of 1,2,3-trichlorodibenzo-p-dioxin, A and 1,2,3,4,7,8-hexachlorodibenzo-p-dioxin, B by Sphingomonas wittichil RW1 (Nam et al. 2006). The compounds in parentheses are very unstable and undergo spontaneous transformation to their respective hydroxylated metabolites. Dibenzo-p-dioxin-1,10a-dioxygenase (1), 1,10a-dihydroxy-1-hydrodibenzo-p-dioxin dehydrogenase (2), 2,2'3-trihydroxydiphenyl ether dioxygenase (3), 2-hydroxy-6-oxo-6-(2-hydroxyphenoxy)-hexa-2,4-dienoic acid hydrolase (4)

be important for survival under the stressed conditions. Fatty acid catabolism and oxidative stress response are important for long-term survival of cells in sand. The transcriptome data indicated salient roles in flagellar activity, pili synthesis, trehalose, and polysaccharide synthesis, and reputed cell surface antigen proteins when grown under stress condition in soil. This demonstrated the competence of genome-wide transposon scanning 
methodologies for evaluation of multiplex traits (Roggo et al. 2013).

The first investigation on protein analysis of RW1 during doxin metabolism was reported by Colquhoun et al. (2012). Some proteins linked to DD/DF degradation were upregulated and cellular stress was increased during DF metabolism. Dioxin dioxygenase was also expressed during growth in both acetate and DF. In another study, 502 proteins were detected when RW1 was grown on DD, DF, and 2-CDD during protein profiling (shotgun proteomics) when compared with growth on acetate. Previous roles of DxnA1A2, DbfB, and DxnB were established and confirmed Swit_3046 dioxygenase and DxnB2 hydrolase role in dioxin degradation (Hartmann and Armengaud 2014).

RNA-Seq (whole transcriptome shotgun sequencing) was also used to profile transcriptional responses of RW1 to DD and DF, while growth in succinic acid served as control. Under these conditions, the protein-coding genes that were expressed differentially in DF were more than 240, while over 300 were expressed in the presence of DD. Stress response genes were upregulated in response to both DD and DF with higher effect in the former than the latter, indicating a higher toxicity of DD when compared with DF (Chai et al. 2016).

Factors determining the biodegradative capacity and environmental behaviour of strain RW1, were performed under near natural conditions (non-sterile DF-contaminated soil) and compared with laboratory culture conditions (RW1 liquid culture in DF) (Moreno-Forero and van der Meer 2015). Reactions were deduced under different growth conditions from analyzing recorded genome-wide expression profiles. RW1 showed stationary phase characteristics, which was evidence of stress, nutrient hunting, and primary metabolism adjustment, if they were not pre-grown in liquid medium with pollutant as established in the soil. Cells multiplying and thriving in sand degraded DF, but displayed a disparate transcriptome indication in liquid culture exposed to drought stress, as well as indication of several 'soil-specific' expressed genes was also deduced. Suggestions were made on inoculation efficacy by testing behaviour of strains under conditions as close to the intended microbiome conditions.

\section{Aerobic degradation of dioxins by other bacterial species}

Bacterial strains other than RW1 that are capable of degrading $\mathrm{DD} / \mathrm{DFs}$ and their chlorinated congeners through the dioxygenation pathways have been isolated and characterized. Most of the isolated dioxinsdegrading bacteria are from Proteobacteria (particularly Betaproteobacteria and Gammaproteobacteria) and
Actinobacteria (mainly Rhodococcus and Terrabacter) (Hiraishi 2003; Chang 2008). Gram-positive bacteria belonging to the phylum Firmicutes initially were not really known for their potential to degrade $\mathrm{DD} / \mathrm{Fs}$, even though some investigators have reported such functionality in some species of Bacillus. There are a few reports on degradation of 2,3,7,8-TCDD by Bacillus megaterium (Matsumura and Benezet 1973), while biosorption of 1,2,3,4-TCDD and other congeners of PCDF by B. pumilis was demonstrated by Hong et al. (2000). Extracts of thermophilic Geobacillus thermodenitrificans UZO 3 have also been shown to degrade 2,3,7,8-TCDD (Suzuki et al. 2016). Furthermore, dreE gene encoding the protein (dioxin reductive etherase) responsible for the reductive cleavage of diaryl ether bond of dioxin associated with the facultative anaerobic strain UZO 3 has been successfully cloned and sequenced (Suzuki et al. 2018). In addition to the technological advancement in molecular biology, Bacillus was implicated as one of the dominant groups of bacteria during degradation studies of dioxins (Chen et al. 2016).

A number of bacterial species utilizing DD/DF for growth as presented in Table 1 include Sphingomonas yanoikuyae B1 (Cerniglia et al. 1979), Sphingomonas sp. HH69 (Fortnagel et al. 1990), S. wittichii RW1 (Wittich et al. 1992; Wilkes et al. 1996), Sphingomonas sp. RW16 (Wittich et al. 1999), Sphingomonas sp. strain HL7 (Fukuda et al. 2002), Comamonas sp. KD7 (Wang et al. 2004), Sphingomonas sp. XLDN2-5 (Gai et al. 2007), and Rhodococcus sp. HA01 (Aly et al. 2008). Application of these organisms as potential candidates for bioremediation (bioaugmentation) of DD/F-contaminated soils has been studied in simulated soil systems. S. wittichii RW1 was inoculated into soil microcosms and DF/DD degradation was monitored (Megharaj et al. 1997; Halden et al. 1999). According to Halden et al. (1999), the degradation rate of the pollutant was greatly influenced by cell population as well as organic matter content of the soil. Similarly, a significant reduction in $\mathrm{PCDD} / \mathrm{F}$ congeners was observed when dioxins-spiked soil was inoculated with Comamonas sp. strain KD7, a DF-degrading bacterium in combination with white clover (Trifolium repens L.) (Wang and Oyaizu 2011).

Cerniglia et al. (1979) transformed DD, DF, and some monochlorinated congeners using biphenyl- and naphthalene-utilizing species of Pseudomonas putida and Sphingobium yanoikuyae. Pseudomonas sp. strain HH69 (formerly Sphingomonas sp. strain HH69) exhibited oxidative activity towards DD and 3-CDF producing catechol, l-hydroxydibenzo- $p$-dioxin, muconic acid derivative, and 4-chlorosalicylic acid, respectively (Harms et al. 1990, 1991). Wittich et al. (1999) reported the degradation of $2-\mathrm{CDF}$ and $3-\mathrm{CDF}$ by a defined bacterial 
Table 1 Bacterial strains capable of degrading dibenzo-p-dioxin, dibenzofuran, and their chlorinated congeners

\begin{tabular}{|c|c|c|c|}
\hline Phylogenetic group/species/strains & Substrate & Mode of dioxygenation & References \\
\hline \multicolumn{4}{|l|}{ ClassAlphaproteobacteria } \\
\hline Sphingomonassp. HH19k & DF & Angular & $\begin{array}{l}\text { Fortnagel et al. (1989); Harms and } \\
\text { Zehnder }(1994,1995)\end{array}$ \\
\hline Sphingomonassp. HH69 & $\begin{array}{l}\text { DD, DF, Monochlorinated DDs/DFs, } \\
\text { Dichlorinated DDs/Fs, Trichlorinated } \\
\text { DD/Fs }\end{array}$ & Angular & $\begin{array}{l}\text { Fortnagel et al. (1989, 1990); Harms et al. } \\
\text { (1990, 1991, 1995); Schreiner et al. } \\
(1997)\end{array}$ \\
\hline Agrobacterium sp. $\mathrm{PH}-08$ & DF & Lateral, Angular & Le et al. (2014) \\
\hline Sphingomonassp. RW16 & DF & Angular & Wittich et al. (1999) \\
\hline Sphingomonaswittichii RW1 & $\begin{array}{l}\text { DD, DF, Monochlorinated DDs/DFs, } \\
\text { Dichlorinated DDs/Fs, Trichlorinated } \\
\text { DD/Fs, Tetra chlorinated DDs }\end{array}$ & Angular & $\begin{array}{l}\text { Wittich et al. (1992), Arfmann et al. } \\
\text { (1997),Armengaud et al. (1998, 1999, } \\
\text { 2000) and Armengaud and Timmis } \\
\text { (1997), Armengaud et al. (1998), Bunz } \\
\text { and Cook (1993), Halden et al. (1999), } \\
\text { Happe et al. (1993), Hong et al. (2002), } \\
\text { Keim et al. (1999), Megharaj et al. } \\
\text { (1997), Wilkes et al. (1996) }\end{array}$ \\
\hline Sphingomonassp. XLDN2-5 & DF & Angular, lateral & Gai et al. (2007) \\
\hline \multicolumn{4}{|l|}{ ClassBetaproteobacteria } \\
\hline Burkholderiasp. LB400 & $\mathrm{DD}, \mathrm{DF}$ & Angular & $\begin{array}{l}\text { Seeger et al. (2001), Erickson and Mon- } \\
\text { dello (1992) }\end{array}$ \\
\hline Burkholderiasp. JB1 & Monochlorinated DDs/DFs & Angular & $\begin{array}{l}\text { Parsons et al. (1998), Parsons and Storms } \\
\text { (1989) }\end{array}$ \\
\hline Burkholderiacepacia F297 & DF & Lateral & Grifoll et al. (1995) \\
\hline Ralstoniasp. SBUG290 & DF, Biphenyl & Lateral & Becher et al. (2000) \\
\hline \multicolumn{4}{|l|}{ Class Gammaproteobacteria } \\
\hline Pseudomonas resinovorans $C A 10$ & $\mathrm{DD}, \mathrm{DF}$ & Angular & $\begin{array}{l}\text { Habe et al. (2001), Maeda et al. (2003), } \\
\text { Nam et al. (2001) }\end{array}$ \\
\hline Pseudomonas putida $\mathrm{PH}-01$ & DF & Angular & Hong et al. (2000) \\
\hline Pseudomonas putida G7 & DF & Lateral & Cerniglia et al. (1979) \\
\hline Pseudomonas putida BS291 & DF & Lateral & Selifonnov et al. (1992) \\
\hline Pseudomonas sp.ISTDF1 & DF & Angular, lateral & Jaiswal et al. (2011) \\
\hline Pseudomonas aeruginosa & DF & Angular, lateral & Ali et al. (2019) \\
\hline $\begin{array}{l}\text { Cycloclasticuspugetii } \\
\text { Pseudomonas aeruginosa FA-HZ1 }\end{array}$ & $\begin{array}{l}\text { DF } \\
\text { DF }\end{array}$ & Angular, lateral & Fuse et al. (2003), Ali et al. (2019) \\
\hline \multicolumn{4}{|l|}{ Phylum Actinobacteria } \\
\hline Rhodococcusopacus SAO01 & $\mathrm{DD}, \mathrm{DF}$ & Angular, lateral & Kimura and Urushigawa (2001) \\
\hline Rhodococcuserythropolis SBUG 271 & DF, Biphenyl & Lateral & Stope et al. (2002) \\
\hline Rhodococcussp. HAO1 & $D F, 2-C D F, 3-C D F$ & Angular, lateral & Aly et al. (2008) \\
\hline Rhodococcussp. p52 & DF & Angular & Peng et al. (2013) \\
\hline Janibacter sp. YY1 & DF & Angular, lateral & Yamazoe et al. (2004) \\
\hline Janibacter terrae XJ-1 & DF & Angular, lateral & Jin et al. (2006) \\
\hline Terrabacter (Janibacter) sp. DPO360 & DF & Angular & Schmidt et al. (1997) \\
\hline Terrabactersp. DBF63 & $\mathrm{DF}, \mathrm{DD}$ & Angular & $\begin{array}{l}\text { Habe et al. (2001, 2002), Kasuga et al. } \\
(1997,2001)\end{array}$ \\
\hline Terrabactersp. YK3 & DF & Angular & lida et al. (2002) \\
\hline \multicolumn{4}{|l|}{ Phylum Firmicutes } \\
\hline Paenibacillus naphthalenovorans 4B1 & DF & Angular & Thanh et al. (2019) \\
\hline
\end{tabular}

consortium consisting of Pseudomonas sp. strain RW10 and Sphingomonas sp. strain RW16 to produce 4-chlorosalicylic acid and 5-chlorosalicylic acid, respectively, which were then utilized and mineralized by strain RW10.

Ralstonia sp. strain SBUG 290 (now reclassified Wautersia sp.) grown on biphenyl cooxidized DF to 
1,2-dihydroxydibenzofuran, which was meta-cleaved between carbon 1 and $9 \mathrm{~b}$ to produce $\mathrm{HOBB}$, a product subsequently metabolized completely through salicylic acid route. Production of these intermediates is an indication of degradation mechanism for DF through lateral dioxygenation by the microorganism (Becher et al. 2000). Sphingomonas sp. strain HL7 and Klebsiella sp. strain HL1 were isolated from dioxin-polluted soil with both exhibiting DF degradation potentials (Fukuda et al. 2002). In addition to DF, strain HL7 also utilized monoand dichlorinated DD/Fs, while strain HL1 could only degrade monochlorinated analogues. The metabolites recovered from the culture fluids of these organisms were similar to those reported for strain RW1 with the exception of catechol and salicylic acid. 4H-1-benzopyran-4-one accumulated, whereas RW1 produced small amount of the compound as well as catechol and a lot of salicylic acid. In addition, strain HL7 had the dioxin dioxygenase alpha-subunit gene of RW1.

Hong et al. (2004) isolated and characterized Pseudomonas veronii $\mathrm{PH}-03$ from a polluted soil following an unusual enrichment procedure. The bacteria was able to grow on DD, DF, 1-CDD, and 2-CDD, and the metabolic intermediates (TrHB, HOPDA, catechol, and salicylic acid) detected and identified showed consistency with the pathway described for dioxin degraders such as strain RW1. In addition to those congeners, resting cells of strain PH-03 transformed TrHB, and 1,2,3,4-TCDD to their respective metabolites such as HOPDA, chlorocatechols, catechol, and salicylic acid. Although there was no production of 3,4,5,6-tetrachlorocatechol from $1,2,3,4$-TCDD, significant growth in the presence of the substrate was not detected, suggesting that $\mathrm{PH}-03$ could not grow on 3,4,5,6-tetrachlorocatechol. DF-grown cells (cell-free extracts), TrHB dioxygenase, HOPDA hydrolase, and catechol activities were all detected. Moreover, the activity of catechol-2,3-dioxygenase and TrHB dioxygenase (in crude cell-free extracts) was inactivated by 3 -chlorocatechol, but no inactivation was detected in whole cells when 3-chlorocatechol was produced.

In another study, the utilization of DF and DD by biphenyl dioxygenase (BPDO) of Burkholderia xenovorans strain LB400 and Comamonas testosteroni strain B-356 was elucidated (L'Abbee et al. 2005). In all cases, the enzymes produced cis-dihydro-dihydroxy DF (main metabolite) in the lateral dioxygenation pathway. Also, the BPDOs produced small amount of THB and THDE from DF and DD, respectively, through angular dioxygenation.

Similarly, naphthalene-degrading bacterium Novosphingobium naphthalenivorans sp. nov., isolated from PCDD-polluted environments co-metabolized DF in the presence of naphthalene with consequent generation of soluble yellow intermediate product which was similar to previously reported studies on naphthalene/DF-degrading bacteria producing a yellow-colored metabolite (HOBB) from aromatic compounds during lateral dioxygenation (Suzuki and Hiraishi 2007).

Rhodococcus sp. strain HA01 was isolated for its ability to grow with DF as the sole source of carbon and energy and could also transform 3-CDF, through angular oxygenation to 4-chlorosalicylic acid stoichiometrically as a dead end product (Aly et al. 2008). In the same vein, 2-CDF was converted to 5 -chlorosalicylic acid by the organism. Lateral oxygenation at positions 3 and 4 , however, yielded a novel metabolite, 2-chloro-3,4-dihydro-3,4-dihydroxydibenzofuran (Aly et al. 2008). Seven strains of Nocardioides aromaticivorans obtained from dioxin-polluted surface water and sediments were reported to possess DF metabolic functionalities (Kubota et al. 2005). Growth of these novel organisms with DF resulted in the production of HOBB.

Janibacter terrae strain XJ-1, isolated from a river sediment in Japan could also grow aerobically on DF as the only carbon source producing TrHB, HOPDA, 3-(chroman-4-on-2-yl) pyruvate, and salicylic acid as intermediates and gentisic acid as the final metabolic product (Jin, et al. 2006). However, with the detection and recovery of 1,2-dihydroxy-1,2-dihydrodibenzofuran from the culture fluid of the bacterium, another pathway was postulated as a secondary route (lateral dioxygenation) at position 1 and 2 carbon atom. In this case, 1,2-dihydroxy-1,2-dihydrodibenzofuran is transformed to 2-hydroxydibenzofuran and 1,2-dihydroxydibenzofuran through spontaneous degradation and, consequently, converted to salicylic acid (Fig. 2). Since traces of the lateral dioxygenation pathway metabolites were spotted, Jin et al. concluded that this catabolic pathway could either be minor in DF catabolism or that it may proceed much more rapidly to prevent metabolite accumulation. Strain XJ-1, therefore, appears to be among the few bacterial strains reported to utilize both lateral and angular dioxygenation for the degradation of DF.

Jaiswal and Thakur (2007) isolated alkalophilic bacterium, Serratia marcescens from pulp and paper industrial effluent by continuous enrichment technique in a chemostat. This organism was able to utilize $80 \%$ of DF within $120 \mathrm{~h}$ through the angular degradation oxidative route. $2,2^{\prime}, 3-\mathrm{THB}$ was detected and no other hydroxyl derivative of DF was formed giving a strong evidence that the bacterium degraded the compound only through the angular catabolic pathway. Pseudomonas strain ISTDF1, another alkalotolerant organism with DF metabolic functions, was also obtained from the same effluent though in a different study (Jaiswal et al. 2011). The bacterium showed substrate-dependent growth over DF which was utilized 
$(100 \mathrm{mg} / \mathrm{l})$ within $30 \mathrm{~h}$ at $\mathrm{pH} 10$ and $40{ }^{\circ} \mathrm{C}$. It was also able to utilize other recalcitrant PAHs and chlorinated xenobiotics. Growth of the organism was unhindered when subjected to varying environmental conditions ( $\mathrm{pH}$, temperature, and DF concentration), thus demonstrating its potential use as candidate organism for onsite bioremediation of dioxin-polluted sites irrespective of the climatic differences. Furthermore, during degradation of DF by this strain, metabolites identified were HOHPDA, gentisic acid, and catechol (angular dioxygenation), while 3-HOBB and 2-(1-carbonyl methylidine)2,3-dihydrobenzofuranlidene were indicator metabolites of lateral dioxygenation. By implication, unlike S. marcescens, strain ISTDF1 was able to metabolize the dioxin molecule through both angular and lateral dioxygenation, resulting in the metabolic pathways summarized in Fig. 6. In this pathway, it is not chemically feasible for the transformation of gentisic acid to catechol to occur, but it is possible for HHOPDA to breakdown to catechol. Agrobacterium sp. $\mathrm{PH}-08$ isolated from a saw mill waste dump site also degraded DF through both angular and lateral dioxygenation (Le et al. 2014). Growth of the organism was also sustainable on biphenyl but not as efficient as when DF was used as carbon. In contrast, growth was not sustainable on other structurally related compounds, including dibenzothiophene, diphenyl ether, and carbazole. However, these compounds could be cometabolically degraded by the organism.

Pseudomonas putida strain B6-2 though isolated from a biphenyl contaminated soil after selective enrichment on biphenyl was found to utilize DF rapidly with production of HOBB (major metabolite), 1-hydroxydibenzofuran and 4-hydroxydibenzofuran (Li et al. 2009) as metabolic products. Pseudomonas mendocina strain NSYSU was also isolated from PCP polluted soil through aerobic selective enrichment procedures (Kao et al. 2005). Lin et al. (2014) showed the strain's ability to degrade PCDD/ Fs under anaerobic conditions in liquid medium and aerobic degradation in PCP and dioxin-contaminated soil slurries. It was able to degrade $70 \%$ of octachlorinated dibenzo- $p$-dioxin (OCDD) and octachlorinated dibenzofuran (OCDF) during the 50-d period of cultivation in liquid medium without formation of less toxic congeners, while about $98 \%$ of OCDD/Fs was degraded in aerobic bioreactor soil slurry after $60 \mathrm{~d}$ of incubation. Also, the effectiveness of using strain NSYSU in the cleanup of OCDF-polluted soils was assessed (microcosm) using lecithin as a carbon source to enhance degradation which eventually resulted in $68 \%$ removal of OCDF after a period of $64 \mathrm{~d}$ (Lin et al. 2017).

Rhodococcus sp. strain p52 was also demonstrated to utilize DF, DD, and substituted analogues aerobically as sole sources of carbon and energy through angular dioxygenation (Peng et al. 2013). In fact, the organism was reported to degrade $500 \mathrm{mg} / \mathrm{l}$ of DF within $48 \mathrm{~h}$, $70 \%$ of $100 \mathrm{mg} / \mathrm{l}$ of $2-\mathrm{DCDF}$ in $96 \mathrm{~h}$, while $100 \mathrm{mg} / \mathrm{l}$ each of DD and 2,8-DCDF were degraded, respectively, by $95 \%$ and 37 in $60 \mathrm{~h}$. In addition, strain p52 was able to metabolize a variety of aromatic compounds, including, dibenzothiophene, biphenyl, naphthalene, fluorene, phenanthrene, anthracene, carbazole, indole, xanthene, phenoxathiin, xanthone, and 9-fluorenone. The bacterium harbors two distinct gene clusters encoding angular dioxygenases DbfA and DfdA. Both gene clusters were located on two different self-transmissible circular plasmids found in the cell (Peng et al. 2013). Paenibacillus naphthalenovorans strain 4B1, isolated from PCCD contaminated soil, could utilize DF within $48 \mathrm{~h}$ incubation, $89 \%$ of 1000 ppm of DF was consumed at $45^{\circ} \mathrm{C}$ through the angular dioxygenation pathway with the expression of the dbf gene (Thanh et al. 2019). In a recent study too, Ali et al. (2019) documented the degradation of DF by Pseudomonas aeruginosa strain FA-HZ1. The organism has a narrow temperature tolerance with a maximum growth and DF degradation rates observed at $30{ }^{\circ} \mathrm{C}$ while preferring weakly acidic environment with an optimum $\mathrm{pH}$ of 5.0 rather than $\mathrm{pH} 7.0$ known for other several species of bacteria. Furthermore, it grew well at DBF concentration that is practically less than $0.5 \mathrm{mM}$ and shaking conditions not over $200 \mathrm{rpm}$. Identified metabolites in the culture fluid implicated both the angular and lateral dioxygenation pathways. Proteomic profiling of this organisms identified 1459 proteins out of which 204 were significantly expressed when the bacterium was grown on DF (Ali et al. 2019). Out of these 204 proteins, 100 were upregulated, whereas 104 were downregulated. Not surprisingly, DF dioxygenase for DF was among the significantly upregulated proteins.

\section{Dioxin degraders as candidate organisms for bioremediation}

Although physical and chemical destruction techniques are available for xenobiotics contamination, environmental regulations and high costs are propelling the search for sustainable technologies for destruction of dioxin pollutants and bioremediation techniques are generally accepted as ecofriendly and cost-effective. Bioremediation generally exploits the metabolic potentials of dioxin-degrading microorganisms. The advantage of this technique lies in its usefulness both in situ and ex situ. The application of this method, however, is limited due to the lack of suitable microorganisms. Interestingly, studies have focused on a lot of bacterial strains capable of utilizing dioxins isolated from polluted and non-polluted environmental matrices as previously discussed. Inoculation of known 


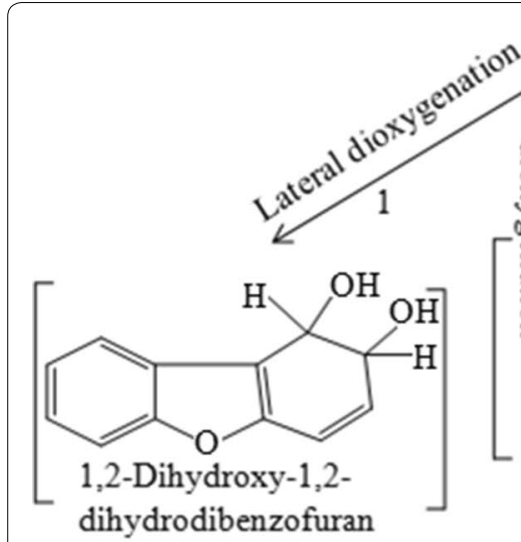<smiles>Oc1cc2c(cc1O)Oc1ccccc1C2</smiles>

2,2'-Dihydroxydibenzofuran

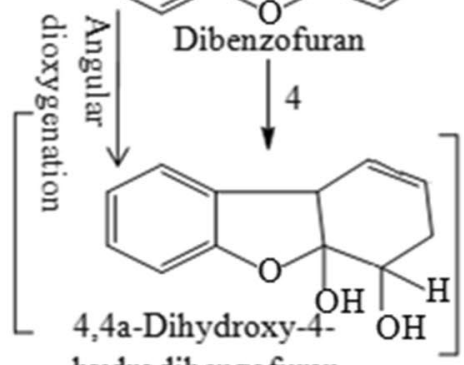
hydrodibenzofuran<smiles>Oc1ccccc1-c1cccc(O)c1O</smiles>

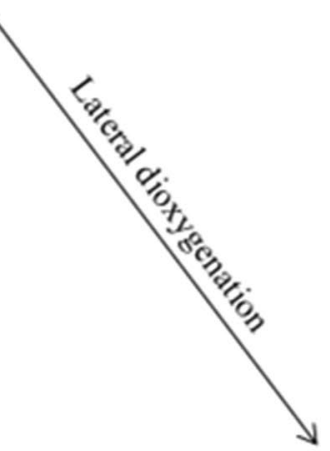<smiles>O=C(O)Cc1oc2ccccc2c1C(O)C(=O)O</smiles>

2-(1-carbonyl methylidine)2,3-dihydrobenzofuranlidene

\section{2,2'3-Trihydroxybiphenyl}<smiles>c1ccc2c(c1)oc1ccccc12</smiles>

Dibenzofuran<smiles>Cc1ccccc1C(=O)CCCC(O)C(=O)O</smiles><smiles>O=CC(O)=CC=C1Oc2ccccc2C1=O</smiles>

2-Hydroxy-6-oxo-6-(2'-hydroxyphenyl)hexa-2,4-dienoic acid

2-Hydroxy-4-(3'-oxo-3'H-benzofuran 2'-yliden)but-2-enoic acid<smiles>O=C(O)c1cc(O)cc(I)c1O</smiles>

Gentisic acid<smiles>Oc1ccccc1O</smiles>

\section{Catechol}

Fig. 6 Metabolic pathways for degradation of dibenzofuran by Pseudomonas sp. strain ISTDF1. The scheme was proposed by Jaiswal et al. (2011) with a slight modification on the basis of metabolites recovered from the culture fluid. Compounds in parentheses (though not assayed) are unstable and spontaneously converted to their respective hydroxylated forms. Arrows designated with question marks are routes that are chemically not feasible. Most likely HOHPDA was converted to salicylic acid before being transformed to gentisic acid. Both gentisic acid and catechol may evolve from HOHPDA simultaneously. (1), Dibenzofuran-1,2-dioxygenase; (2), 1,2-dihydroxy-1,2-dihydrodibenzofuran dehydrogenase; (3), 1,2-dihydroxybenzofuran dioxygenase; (4), Dibenzofuran-4,4a-dioxygenase; (5), 4,4a-dihydroxy-4-hydro-dibenzofuran dehydrogenase, and (6), 2,2',3-trihydroxybiphenyl dioxygenase 
dioxin-degrading bacteria to a polluted environment to enhance the degradation of pollutants, where indigenous microorganisms do not have the capacity to degrade these xenobiotics, might be the only approach for successful bioremediation. Several studies have investigated the bioremediation of dioxins using pure bacterial culture or consortia. Aerobic strains such as Sphingomonas wittichii RW1, Terrabacter sp. strain DBF63, and Sphingomonas sp. strain KA1, have been demonstrated unequivocally to degrade DD, DF, and some chlorinated analogues in soil slurry (Halden et al. 1999; Habe et al. 2001, 2002). This was investigated in laboratory soil systems by pure culture or consortia seeding with externally added dioxins or polluted soils. Typical results suggested the prospects of such strains as candidates for PCDD/Fs cleanup from the environment.

Strain KA1 degraded $96 \%$ and $70 \%$ of $2-C D D$ and 2,3-CDD, respectively, after a 7-d incubation in dioxincontaminated model soil (Halden et al. 1999). Also, the removal of $10 \mathrm{ppm}$ each of DD, DF, and 2-CDD from soil microcosms upon seeding with strain RW1 was observed. The rate of removal was influenced by cell density and soil organic matter content.

Application of Terrabacter sp. DBF63 to dioxincontaminated soil slurry system was documented by Habe et al. (2002). According to the authors, the DFgrown cells degraded 90\% 2,8-DCDF (1 ppm) in $7 \mathrm{~d}$, even though $76-80 \%$ removal was observed within the first $d$ of incubation, indicating that prolonged incubation did not significantly improve degradation. On the other hand, only $40 \%$ depletion was obtained for 2,3-DCDD under the same conditions of treatment. When the study was expanded to include other congeners in separate soil slurry, Habe et al. showed that strain DBF63 consumed within 5 d 2-CDF, 2-CDD, 2,8DCDF, and 2,3-DCDF by approximately $93 \%, 79 \%, 81 \%$, and $40 \%$ respectively. Similar to initial data obtained from 2,8-DCDF and 2,3-DCDF degradation, 2-CDF was degraded more than 2-CDD, both of which have chlorine substitution at position 2 of the DF and DD skeleton respectively. Seeding of the organism with dioxin-polluted soil from an incinerator site revealed a decrease in PCDD/F concentration (10 ng/g-soil). A critical examination of the congeners in the contaminated soil showed $10 \%$ depletion in the levels of tetrato hexaCDD/F whereas hepta- to octaCDD/F remained unchanged (Habe et al. 2002).

A microbial biocatalyst (4 bacteria and 5 fungi with dioxin-degrading capabilities) was used to degrade $\mathrm{PCDD} / \mathrm{Fs}$ in an incinerator fly ash in solid-state fermentation setup (Nam et al. 2008). Treated sample indicated reduction $(68.7 \%)$ of the total toxic $\mathrm{PCDD} / \mathrm{Fs}$ and removal of 2,3,7,8-substituted analogues (66.8\%) after 21 $\mathrm{d}$, while denaturing gradient gel electrophoresis (DGGE) was used to monitor the viability of the strains making up the microbial biocatalyst during the incubation period. The analysis indicated the presence of all the bacterial and fungal strains (microbial catalyst) during the incubation period.

Alkalotolerant bacterial community inoculated into soil microcosm resulted in varying levels of DF degradation (Sahni et al. 2011). Consortium enriched for $180 \mathrm{~d}$ showed maximum degradation compared to those with 45 and $90 \mathrm{~d}$ adaptation. The bacterial community analysis observed that the community was efficient and still retained its degrading abilities in in situ conditions.

In Chen et al. (2014), soil samples containing high concentration of OCDF were used for microcosm study and bacterial communities involved in OCDF degradation were monitored using high-throughput pyrosequencing. Bacterial community succession rapidly changed with consequent degradation of OCDF. Sphingomonas, Pseudomonas, Clostridium, and Rhodococcus, were implicated as potential degraders, while Brevundimonas, Pseudoxanthomonas, and Lysobacter showed a huge increase in their 16S rRNA gene copies during the temporal population dynamics. In another study, Wu et al. (2019) observed the effects of redox fluctuations in PCDD/ Fs degradation in a bioreactor (two fed-batch continuous stirred tank) under hypoxic conditions. Redox fluctuations at a narrow range showed a higher PCDD/F degradation rate when compared with the redox potential fluctuations at a broad range. Consequently, species diversity was higher with dominance of Actinobacteria, Bacteroidetes, and Alphaproteobacteria in the narrowrange redox fluctuation.

In many studies where microbial seeding for contaminant cleanup has been a failure, several physicochemical parameters were believed to be responsible. According to Thompson and coworkers (2005), failure has often been attributed to choosing bioaugmentation as the remediation approach without thorough understanding of the fundamentals and rules of engagement. Investigators are too quick to jump into conclusions and generally are wont to make universal proclamations. Organisms that work best in liquid culture conditions in the laboratory may not necessarily do well in natural contaminated systems. It is this gap in knowledge of the composition and population dynamics of some communities as well as those of the target habitats, the procedure for microbial seeding, persistence and performance of inoculated stains, and the sole preoccupation with the vigorous search for competent degraders as the root of many failures. Taking these conditions into cognizance, Tu et al. (2014) investigated bioremediation candidacy of $P$. mendocina 
NSYSU for cleanup of OCDD both in microcosm and at a pilot-scale. Preliminary experiments indicated that strain NSYSU could grow aerobically and anaerobically under $5 \%$ salinity conditions. In microcosm setups, the organism degraded up $62 \%$ of OCDD after 65 d under anaerobic conditions. Lecithin was found to enhance metabolism by $9 \%$ (71\%). Results emanating from the pilot-scale study indicated that nearly $75 \%$ of OCDD was metabolized with the addition of lecithin with no traceable metabolite production. Lecithin is known to form either liposomes, bilayer sheets, micelles, or lamellar structures, and thus, its addition improved the affinity of the dioxin to strain NSYSU, resulting in enhanced degradation. It must be mentioned that this activity of NSYSU was only observed in inoculated pilot and microcosm systems. The organism could not do well in non-sterilized soils where indigenous microflora outcompeted it. This means that the removal efficiency of OCDD could be enhanced with periodical seeding to maintain a higher population of strain NSYSU (Tu et al. 2014).

Composts of various sources were used to set up microcosm experiments in a bioreactor which was developed to reduce $\mathrm{PCDD} / \mathrm{Fs}$ in contaminated soils maintained under hypoxic conditions (Chen et al. 2016). PCDD/ Fs degradation in the soil samples was facilitated during amendment of cow dung and waste sludge compost. Bacterial species richness increased in the contaminated soil which varied with the compost source. Actinobacteria, Alphaproteobacteria, Gammaproteobacteria, and Firmicutes were the dominant bacterial phyla. Rapid degradation of $\mathrm{PCDD} / \mathrm{Fs}$ correlated with bacterial growth. Also, Huang et al. (2019) monitored the degradation of PCCD/Fs-contaminated soil and bacterial communities during aerobic food waste co-composting, Though the microflora was largely dominated by the Firmicutes, other prominent phyla are Actinobacteria, Proteobacteria, and Bacteroidetes, while Bacillus was the dominant genus with consequent $75 \%$ degradation of toxic equivalent quantity.

All studies so far described emanated mostly from soil slurry and microcosm laboratory experiments with few from bioreactors and pilots systems. The extensive knowledge on microbial degradation of dioxins bothered mainly on liquid culture studies. Field studies for deployment of microorganisms for cleanup of dioxin-contaminated soil are not yet available, perhaps, still under investigation. Nevertheless, results so far obtained from laboratory investigations are very encouraging and generally re-awaken the hope that future cost-effective and environmentally-friendly techniques for total destruction of dioxins, perhaps, solely lie in the scavenging activities of microorganisms once the ground rules of engagement between the target pollutants and the microbial communities are fully understood.

\section{Future prospects}

Globally, it has been shown that eastern North America, Europe, and South and East Asia have the highest dioxin concentration in the environment, due to industrial and uncontrolled combustion activities (Dopico and Gómez 2015). Dioxins are deposited into the environment through various chemical operations and dispersal of dioxins originating from obscure activities (secondary emission). Africa is the most affected through secondary emission due to the fact that out of the top 20 dioxin impacted countries, 11 countries are from Africa when ambient concentration with the ratio of production is compared. This can be found in North African countries like Egypt, which receives PCDD/Fs from Europe apart from their own production of dioxins (Booth et al. 2013). However, currently, there is scanty information regarding dioxin concentration (polluted sites) in the Africa continent when compared to Europe, Asia, and America. The implementation of policies, social awareness campaigns, and enactment of strict legislation has consequently reduced dioxin emission levels in these developed countries. However, in Africa, there is still lack of appropriate regulatory acts and social awareness on dioxins emission. Data available for levels and distribution of dioxins are limited which is important for further research and observation of the environment. It is imperative to have a detailed information on the emission, transportation, degradation, and precise mapping out of dioxincontaminated sites in Africa, especially Nigeria which is the most populous country in the continent where there is still indiscriminate burning of waste, and use of banned chemicals and pesticides.

\section{Conclusion}

The use of powerful molecular tools to detect large-scale bacterial populations from polluted unexplored environments will go a long way in developing more bacterial strains with unique metabolic features which can be applied for effective bioremediation in dioxin-polluted sites. Use of metagenomics tools should be applied during bioremediation in dioxin-polluted sites, which will be able to detect active bacterial communities (metatranscriptomics) with dioxin metabolic capacity. Since dioxins are present in water, soil, and sediments, it is necessary to develop multiple bioremediation methodologies (biostimulation and bioaugmentation) appropriate for individual contaminated sites as well as pre-culture of known degraders in a mimicked polluted medium prior to inoculation in the polluted soil. Aerobic biodegradation of dioxins by bacterial dioxygenase systems 
is only applicable for the destruction of low chlorinated analogues (monochlorinated congeners-to-tetrachlorinated congeners). However, 2,3,7,8-TCDD, other toxic $\mathrm{PCCD} / \mathrm{F}$ congeners and toxic chlorocatechols remain difficult to mineralize by bacterial dioxygenase enzymes. The engineering of microorganisms and their enzymes to have a wide substrate spectrum may produce strains with exotic catabolic features with improved efficacy for bioremediation.

\begin{abstract}
Abbreviations
BPDO: Biphenyl-2,3-dioxygenase; BPDO: Biphenyl dioxygenase; CDD Chlorodibenzo-p-dioxin; CDF: Chlorodibenzofuran; DCDF: Dichlorodibenzofuran; DF: Dibenzofuran; DD: Dibenzo-p-dioxin; DD/F: Dibenzo-p-dioxin/ furan; DGGE: Denaturing gradient gel electrophoresis; $\gamma-\mathrm{HCH}$ : Gammahexachlorocyclohexane; HeCDD: Hexachlorodibenzo-p-dioxin; HOBB: 2-Hydroxy-4-(3'0xo-3'H-benzofuran-2'-yliden)but-2-enoic acid; HOHPDA: 2-Hydroxy-6-oxo-6-(2-hydroxyphenyl)-hexa-2,4-dienoic acid; HOPDA: 2-Hydroxy-6-oxo-6-phenylhexa-2,4-dienoic acid; OCDD: Octachlorinated dibenzo-p-dioxin; OCDD/Fs: Octachlorinated dibenzo-p-dioxin/furans; OCDF: Octachlorinated dibenzofuran; PAHs: Polycyclic aromatic hydrocarbons; PCBs: Polychlorinated biphenyls; PCDDs: Polychlorinated dibenzo-p-dioxins; PCDFs: Polychlorinated dibenzofurans; PCDD/Fs: Polychlorinated dibenzo-p-dioxin/ furans; PCP: Pentachlorophenol; PeCDD: Pentachlorodibenzo-p-dioxin; POPs: Persistent organic pollutants; RDH: Reductive dehalogenases; TCDD: Tetrachlorodibenzo-p-dioxin; THB: 2,2',3-trihydroxybiphenyl; TrCDD: Trichlorodibenzop-dioxin; TrCDF: Trichlorodibenzofuran; TrHB: 2,2',3-Trihydroxybiphenyl; TrHDE: 2,2'3-Trihydroxydiphenyl ether.
\end{abstract}

\section{Acknowledgements}

Not applicable.

\section{Authors' contributions}

SB collected related materials and drafted the manuscript. SAA conceptualized the work. SAA and $\mathrm{GOO}$ revised and edited the manuscript. All authors read and approved the final manuscript.

\section{Funding}

Not applicable.

\section{Availability of data and materials}

All data generated or analyzed during this study are included in this published article.

\section{Ethics approval and consent to participate}

Not applicable.

\section{Consent for publication}

Not applicable.

\section{Competing interests}

The authors declare that they have no competing interests.

Received: 28 September 2019 Accepted: 20 January 2020

Published online: 11 February 2020

\section{References}

Adebusoye SA, llori MO, Picardal FW, Amund OO (2008) Extensive biodegradation of polychlorinated biphenyls in Aroclor 1242 and electrical transformer fluid (Askarel) by natural strains of microorganisms indigenous to contaminated African systems. Chemosphere 73:126-132

Ali F, Hu H, Wang W, Zhou Z, Shah SB, Xu P, Tang H (2019) Characterization of a dibenzofuran-degrading strain of Pseudomonas aeruginosa, FA-HZ1. Environ Pollut 250:262-273
Aly HAH, Huu NB, Wray V, Junca H, Pieper DH (2008) Two angular dioxygenases contribute to the metabolic versatility of dibenzofuran-degrading Rhodococcus sp. strain HA01. Appl Environ Microbiol 74:3812-3822

Arfmann H, Timmis KN, Wittich R (1997) Mineralization of 4-chlorodibenzofuran by a consortium consisting of Sphingomonas sp. strain RW1 and Burkholderia sp. strain JWS. Appl Environ Microbiol 63:3458-3462

Armengaud J, Timmis KN (1997) Biodegradation of dibenzo-p-dioxins and dibenzofurans by bacteria. J Microbiol 4:241-252

Armengaud J, Happe B, Timmis KN (1998) Genetic analysis of dioxin dioxygenase of Sphingomonas sp. strain RW1: catabolic genes dispersed on the genome. J Bacteriol 180:3954-3966

Armengaud J, Timmis KN, Wittich RM (1999) A functional 4-hydroxysalicylate/ hydroxyquinol degradative pathway gene cluster is linked to the initial dibenzo-p-dioxin pathway genes in Sphingomonas sp. strain RW1. J Bacteriol 181:3452-3461

Barkovskii AL, Adriaens P (1996) Microbial dechlorination of historically present and freshly spiked chlorinated dioxins and diversity of dioxin dechlorinating populations. Appl Environ Microbiol 62:4556-4562

Becher D, Specht M, Hammer E, Francke W, Schauer F (2000) Cometabolic degradation of dibenzofuran by biphenyl cultivated Ralstonia sp. strain SBUG 290. Appl Environ Microbiol 66:4528-4531

Bedard DL (2008) A case study for microbial biodegradation: anaerobic bacterial reductive dechlorination of polychlorinated biphenyls-from sediment to defined medium. Ann Rev Microbiol 62:253-270

Bertazzi PA, Bernucci I, Brambilla G, Consonni D, Pesatori AC (1998) The Seveso studies on early and long-term effects of dioxin exposure: a review. Environ Health Perspect 106:625-633

Booth S, Hui J, Alojado Z, Lam V, Cheung W, Zeller D, Steyn D, Pauly D (2013) Global deposition of airborne dioxin. Mar Pollut Bull 75:182-186

Bunge M, Adrian L, Kraus A, Opel M, Lorenz WG, Andreesen JR, Gorisch H, Lechner U (2003) Reductive dehalogenation of chlorinated dioxins by an anaerobic bacterium. Nature 421:357-360

Bunz PV, Cook AM (1993) Dibenzofuran 4,4a-dioxygenase from Sphingomonas sp. strain RW1: angular dioxygenation by a three-component enzyme system. J Bacteriol 175:6467-6475

Cerniglia C, Morgan J, Gibson D (1979) Bacterial and fungal oxidation of dibenzofuran. Biochem J 180:175-185

Chai B, Tsoi TV, Iwai S, Liu C, Fish JA, Gu C, et al (2016) Sphingomonas wittichii Strain RW1 Genome-wide gene expression shifts in response to dioxins and clay. PLoS ONE 11(6): e0157008. doi:https://doi.org/10.1371/journ al.pone.0157008.

Chang YS (2008) Recent developments in microbial biotransformation and biodegradation of dioxins. J Mol Microbiol Biotechnol 15:152-171

Chen WY, Wu JH, Chang JE (2014) Pyrosequencing analysis reveals high population dynamics of the soil Microcosm degrading octachlorodibenzofuran. Microbes Environ 29:393-400

Chen WY, Wu JH, Lin YY, Huang HJ, Chang JE (2013) Bioremediation potential of soil contaminated with highly substituted polychlorinated dibenzop-dioxins and dibenzofurans: Microcosm study and microbial community analysis. J Hazard Mater 261:351-361

Chen WY, Wu JH, Lin SC, Chang JE (2016) Bioremediation of polychlorinated-pdioxins/dibenzofurans contaminated soil using simulated compostamended landfill reactors under hypoxic conditions. J Hazard Mater 312:159-168

Colquhoun DR, Hartmann EM, Halden RU (2012) Proteomic profiling of the dioxin-degrading bacterium Sphingomonas wittichii RW1. J Biomed Biotechnol. 2012:408690

Consonni D, Angela CP, Carlo Z, Raffaella S, Luca C, D'Oro Maurizia R, Pier $A B(2008)$ Mortality in a population exposed to dioxin after the seveso, italy, accident in 1976: 25 years of follow-up. Am J Epidemiol $167: 847-858$

Coronado E, Roggo C, Johnson DR, van der Meer JR (2012) Genome-wide analysis of salicylate and dibenzofuran metabolism in Sphingomonas wittichii RW1. Front Microbiol 3:300

Dopico M, Gómez A (2015) Review of the current state and main sources of dioxins around the world. J Air Waste Manag Assoc 65:1033-1049

Erickson BD, Mondello FJ (1992) Nucleotide sequencing and transcriptional mapping of the genes encoding biphenyl dioxygenase, a multicomponent polychlorinated-biphenyl-degrading enzyme in Pseudomonas strain LB400. J Bacteriol 174:2903-2912 
Fennell DE, Nijenhuis I, Wilson SF, Zinder SH, Haggblom MM (2004) Dehalococcoides ethenogens strain 195 reductively dechlorinate diverse chlorinated aromatic pollutants. Environ Sci Technol 38:2075-2081

Field JA, Sierra-Alvarez R (2008) Microbial degradation of chlorinated dioxins. Chemosphere 71:1005-1018

Fortnagel P, Harms H, Wittich RM, Francke W, Krohn S, Meyer H (1989) Cleavage of dibenzofuran and dibenzodioxins ring systems by a Pseudomonas bacterium. Sci Nature 76(5):222-223

Fortnagel P, Harms H, Wittich RM, Krohn S, Meyer H, Sinnwell V et al (1990) Metabolism of dibenzofuran by Pseudomonas sp. strain $\mathrm{HH} 69$ and the mixed culture HH27. Appl Environ Microbiol 56:1148-1156

Fukuda K, Nagata S, Taniguchi H (2002) Isolation and characterization of dibenzofuran-degrading bacteria. FEMS Microbiol Lett 208:179-185

Fuse H, Takimura O, Murakami K, Inoue H, Yamaoka Y (2003) Degradation of chlorinated biphenyl, dibenzofuran, and dibenzo-p-dioxin by marine bacteria that degrade biphenyl, carbazole, or dibenzofuran. Biosci Biotech Biochem 67:1121-1125

Gai Z, Yu B, Li L, Wang Y, Ma C, Feng J, Deng Z, Xu P (2007) Cometabolic degradation of dibenzofuran and dibenzothiophene by a newly isolated carbazole-degrading Sphingomonas sp. strain. Appl Environ Microbiol 73:2832-2838

Ghimpetxeanu OM, Militaru M, Scippo ML (2014) Dioxins and polychlorinated biphenyls contamination in poultry liver related to food safety - a review. Food Control 38:47-53

Gioia R, Akindele AJ, Adebusoye SA, Asante KA, Tanabe S, Buekens A, Sasco AJ (2014) Polychlorinated biphenyls (PCBs) in Africa: a review of environmental levels. Environ Sci Pollut R 21:6278-6289

Grifoll M, Selifonov SA, Chapman PJ (1995) Transformation of substituted fluorenes and fluorene analogs by Pseudomonas sp. strain F274. Appl EnvironMicrobiol 61:3490-3493

Habe H, Chung JS, Lee JH, Kasuga K, Yoshida T, Nojiri H, Omori T (2001) Degradation of chlorinated dibenzofurans and dibenzo-p-dioxins by two types of bacteria having angular dioxygenases with different features. Appl Environ Microbiol 67:3610-3617

Habe H, Ide K, Yotsumoto M, Tsuji H, Yoshida T, Nojiri H, Omori T (2002) Degradation characteristics of a dibenzofuran-degrader Terrabacter sp. strain DBF63 toward chlorinated dioxins in soil. Chemosphere 48:201-207

Halden RU, Halden BG, Dwyer DF (1999) Removal of dibenzofuran, dibenzo$p$-dioxin, and 2-chlorodibenzo-p-dioxin from soils inoculated with Sphingomonas sp. strain RW1. Appl Environ Microbiol 65:2246-2249

Happe B, Eltis LD, Poth H, Hedderich R, Timmis KN (1993) Characterization of 2, 2', 3-trihydroxybiphenyl dioxygenase, an extradioldioxygenase from the dibenzofuran-and dibenzo-p-dioxin-degrading bacterium Sphingomonas sp. strain RW1. J Bacteriol 175:7313-7320

Harms H, Wittich RM, Sinnwell V, Meyer H, Fortnagel P, Francke W (1990) Transformation of dibenzo-p-dioxin by Pseudomonas sp. strain HH69. Appl Environ Microbiol 56:1157-1159

Harms H, Zehnder AJ (1994) Influence of substrate diffusion on degradation of dibenzofuran and 3-chlorodibenzofuran by attached and suspended bacteria. Appl EnvironMicrobiol 60:2736-2745

Harms H, Zehnder A (1995) Bioavailability of sorbed 3-chlorodibenzofuran. Appl EnvironMicrobiol 61:27-33

Harms H, Wilkes H, Sinnwell V, Wittich RM, Figge K, Francke W, Fortnagel P (1991) Transformation of 3-chlorodibenzofuran by Pseudomonas sp. HH69. FEMS Microbiol Lett 65:25-29

Harms H, Wilkes H, Wittich RM, Fortnagel P (1995) Metabolism of hydroxydibenzofurans, methoxydibenzofurans, acetoxydibenzofurans, and nitrodibenzofurans by Sphingomonas sp. strain HH69. Appl Environ Microbiol 61:2499-2505

Hartmann EM, Armengaud J (2014) Shotgun proteomics suggests involvement of additional enzymes in dioxin degradation by Sphingomonas wittichii RW1 Environmental Microbiology. Special Issue: Metabolism \& Biodegradation. 16:162-176

Hay A (1977) Seveso: dioxin damage. Nature 266:7-8

Hay A (1978) Vietnams dioxin problem. Nature 271:597-598

Hiraishi A (2003) Biodiversity of dioxin-degrading microorganisms and potential utilization in bioremediation. Microbes Environ 18:105-125

Hoekstra EJ, de Weerd H, de Leer EW, Brinkman UAT (1999) Natural formation of chlorinated phenols, dibenzo-p-dioxins, and dibenzofurans in soil of a Douglas fir forest. Environ Sci Technol 33:2543-2549
Holscher T, Krajmalnik-Brown R, Ritalahti KM, von Wintzingerode F, Gorisch H, Loffler FE, Adrian L (2004) Multiple non-identical reductive dehalogenase homologous gene are common in Dehalococcoides. Appl Environ Microbiol 70:5290-5297

Hong HB, Hwang SH, Chang YS (2000) Biosorption of 1,2,3,4-tetrachlorodibenzo- $p$-dioxin and polychlorinated dibenzofurans by Bacillus pumilus. Water Res 34:349-353

Hong HB, Chang YS, Nam IH, Fortnagel P, Schmidt S (2002) Biotransformation of 2,7-dichloro- and 1,2,3,4-tetrachlorodibenzo-p-dioxin by Sphingomonas wittichii RW1. Appl Environ Microbiol 68:2584-2588

Hong HB, Nam IH, Murugesan K, Kim YM, Chang YS (2004) Biodegradation of dibenzo-p-dioxin, dibenzofuran, and chlorodibenzo-p-dioxins by Pseudomonas veronii $\mathrm{PH}-03$. Biodegradation 15:303-313

Huang WY, Ngo HH, Lin C, Vu CT, Kaewlaoyoong A, Boonsong T, Trana HT, Bui XT, Voa TDH, Chen JR (2019) Aerobic co-composting degradation of highly PCDD/F-contaminated field soil. A study of bacterial community. Sci Total Environ 660:595-602

lida T, Mukouzaka Y, Nakamura K, Kudo T (2002) Plasmid-borne genes code for an angular dioxygenase involved in dibenzofuran degradation by Terrabacter sp. strain YK3. Appl Environ Microbiol 68:3716-3723

Iwasaki T, Takeda H, Miyauchi K, Yamada T, Masai E, Fukuda M (2007) Characterization of two biphenyl dioxygenases for biphenyl-PCB degradation in a PCB degrader, Rhodococcus sp strain RHA1. Biosci Biotechnol Biohem 71(4):993-1002

Jaiswal PK, Thakur IS (2007) Isolation and characterization of dibenzofurandegrading Serratia marcescens from alkalophilic bacterial consortium of the chemostat. Curr Microbiol 55:447-454

Jaiswal PK, Kohli S, Gopal M, Thakur IS (2011) Isolation and characterization of alkalo tolerant Pseudomonas sp. strain ISTDF1 for degradation of dibenzofuran. J Ind Microbiol Biotechnol 38:503-511

Jeon JR, Murugesan K, Baldrian P, Schmidt S, Chang YS (2016) Aerobic bacterial catabolism of persistent organic pollutants - potential impact of biotic and abiotic Interaction. Curr Opin Biotechnol 38:71-78

Jin S, Zhu T, Xu X, Xu Y (2006) Biodegradation of dibenzofuran by Janibacter terrae strain XJ-1. Curr Microbiol 53:30-36

Johnson DR, Coronado E, Moreno-Forero SK, Heipieper HJ, van der Meer JR (2011) Transcriptome and membrane fatty acid analyses reveal different strategies for responding to permeating and non-permeating solutes in the bacterium Sphingomonas wittichii. BMC Microbiol 11:250

Kaiser J (2000) Toxicology. Just how bad is dioxin? Science 288:1941-1944

Kao CM, Chen SC, Liu JK, Wu MJ (2001) Evaluation of TCDD biodegradability under different redox conditions. Chemosphere 44:1447-1454

Kao CM, Liu JK, Chen YL, Chai CT, Chen SC (2005) Factors affecting the biodegradation of PCP by Pseudomonas mendocina NSYSU. J Hazard Mater 124:68-73

Kasuga K, Nojiri H, Yamane H, Kodama T, Omori T (1997) Cloning and characterization of the genes involved in the degradation of dibenzofuran by Terrabacter sp. strain DBF63. J Ferment Bioeng 84:387-399

Kasuga K, Habe H, Chung JS, Yoshida T, Nojiri H, Yamane H, Omori T (2001) Isolation and characterization of the genes encoding a novel oxygenase component of angular dioxygenase from the gram-positive dibenzofuran-degrader Terrabacter sp. strain DBF63. Biochem Biophys Res Comm 283:195-204

Kearny PC, Ellington Woolson EA, Jr CP (1972) Persistence and metabolism of chlorodioxins in soils. Environ Sci Technol 6:1017-1019

Keim T, Francke W, Schmidt S, Fortnagel P (1999) Catabolism of 2,7-dichloroand 2,4,8-trichlorodibenzofuran by Sphingomonas sp strain RW1. J Ind Microbiol Biotechnol 23:359-363

Kimura N, Urushigawa Y (2001) Metabolism of dibenzo-p-dioxin and chlorinated dibenzo-p-dioxin by a gram-positive bacterium, Rhodococcus opacus SAO 101. J Biosci Bioeng 92:138-143

Klees M, Hiester E, Bruckmann P, Molt K, Schmidt TC (2015) Polychlorinated biphenyls, polychlorinated dibenzo-p-dioxins and dibenzofurans in street dust of North Rhine-Westphalia, Germany. Sci Total Environ 511:72-81

Kubota M, Kawahara K, Sekiya K, Uchida T, Hattori Y, Futamata H, Hiraishi A (2005) Nocardioides aromaticivorans sp. nov., a dibenzofuran-degrading bacterium isolated from dioxin-polluted environments. Syst Appl Microbiol 28:165-174

Kulkarni PS, Crespo JG, Afonso CAM (2008) Dioxins sources and current remediation technologies—a review. Environ Int 34:139-153 
Kumar P, Mohammadi M, Dhindwal S, Pham TTM, Bolin JT, Sylvestre M (2012) Structural insights into the metabolism of 2-chlorodibenzofuran by an evolved biphenyl dioxygenase. Biochem Biophys Res Commun 421:757-762

L'Abbee JB, Barriault D, Sylvestre M (2005) Metabolism of dibenzofuran and dibenzo-p-dioxin by the biphenyl dioxygenase of Burkholderia xenovorans LB400 and Comamonas testosterone B-356. Appl Microbiol Biotechnol 67:506-514

Le TT, Murugesan K, Nam IH, Jeon JR, Chang YS (2014) Degradation of dibenzofuran via multiple dioxygenation by a newly isolated Agrobacterium sp. PH-08. J Appl Microbiol 116:542-553

Li Q, Wang X, Yin G, Gai Z, Tang H, Ma C, Deng Z, Xu P (2009) New metabolites in dibenzofuran cometabolic degradation by a biphenyl-cultivated Pseudomonas putida strain B6-2. Environ Sci Technol 43:8635-8642

Lin WC, Chien GPC, Kao CM, Newman L, Wong TY, Liu JK (2014) Biodegradation of Polychlorinated dibenzo-p-dioxins by Pseudomonas mendocina Strain NSYSU. J Environ Qual 43:349-357

Lin X, Yan M, Dai A, Zhan M, Fu J, Li X, Yan J (2015) Simultaneous suppression of $\mathrm{PCDD} / \mathrm{F}$ and NOx during municipal solid waste incineration. Chemosphere 126:60-66

Lin JL, Lin WC, Liu JK, Surampalli RY, Zhang TC, Kao CM (2017) Aerobic biodegradation of OCDD by P. mendocina NSYSU: effectiveness and gene inducement studies. Water Environ Res 89:2113-2121

Liu X, Wang J, Wang X, Zhu T (2015) Simultaneous removal of PCDD/Fs and NOx from the flue gas of a municipal solid waste incinerator with a pilot plant. Chemosphere 133:90-96

Maeda K, Nojiri H, Shintani M, Yoshida T, Habe H, Omori T (2003) Complete nucleotide sequence of carbazole/dioxin-degrading plasmid PCAR1 in Pseudomonas resinovorans strain CA10 indicates its mosaicity and the presence of large catabolic transposon Tn4676. J MolBiol 326:21-33

Matsumura F, Benezet HJ (1973) Studies on the bioaccumulation and microbial degradation of 2,3,7,8-tetrachlorodibenzo-p-dioxin. Environ Health Perspect 5:253-258

McLachlan MD, Horstmann M, Hinkel M (1996) Polychlorinated dibenzo-p-dioxins and dibenzofurans in sewage sludge: Sources and fate following sludge application to land. Sci Total Environ 185:109-123

Megharaj M, Wittich RM, Blasco R, Pieper DH, Timmis KN (1997) Superior survival and degradation of dibenzo-p-dioxin and dibenzofuran in soil by soil-adapted Sphingomonas sp. strain RW1. Appl Microbiol Biotechnol 48:109-114

Miller TR, Dellcher AL, Salzberg SL, Saunders E, Detter JC, Halden RU (2010) Genome sequence of the dioxin-mineralizing bacterium Sphingomonas wittichii RW1. J Bacteriol 192:1601-1602

Miyauchi K, Sukda P, Nishida T, Ito E, Matsumoto Y, Masai E, Fukuda M (2008) Isolation of dibenzofuran-degrading bacterium, Nocardioides sp. DF412 and characterization of its dibenzofuran degradation genes. J Biosci Bioeng 105:628-635

Mohammadi M, Sylvestre M (2009) Resolving the profile of metabolites generated during oxidation of dibenzofuran and chlorodibenzofurans by the biphenyl catabolic pathway enzymes. ChemBiol 12:835-846

Mohammadi M, Viger J-F, Kumar P, Barriault D, Bolin JT, Sylvestre M (2011) Returning rieske-type oxygenases to expand substrate range. J Biol Chem 286(31):27612

Moreno-Forero SK, van der Meer JR (2015) Genome-wide analysis of Sphingomonas wittichii RW1 behaviour during inoculation and growth in contaminated sand. ISME J 9:150-165

Nam JW, Nojiri H, Yoshida T, Habe H, Yamane H, Omori T (2001) New classification system for oxygenase components involved in ring-hydroxylating oxygenations. Biosci Biotech Biochem 65:254-263

Nam IH, Kim YM, Schmidt S, Chang YS (2006) Biotransformation of 1,2,3-Triand 1,2,3,4,7,8 hexachlorodibenzo-p-dioxin by Sphingomonas wittichii strain RW1. Appl Environ Microbiol 72:112-116

Nam IH, Kim YM, Murugesan K, Jeon JR, Chang YY, Chang YS (2008) Bioremediation of PCDD/Fs-contaminated municipal solid waste incinerator fly ash by a potent microbial biocatalyst. J Hazard Mater 157:114-121

Nojiri H, Omori T (2002) Molecular bases of aerobic bacterial degradation of dioxins: involvement of angular dioxygenation. Biosci Biotechnol Biochem 66:2001-2016

Nojiri H, Habe H, Omori T (2001) Bacterial degradation of aromatic compounds via angular dioxygenation. J Gen Appl Microbiol 47:279-305
Palanisami N, Chung SJ, Moon IS (2015) Cerium(IV)-mediated electrochemical oxidation process for removal of polychlorinated dibenzo-p-dioxins and dibenzofurans. J Ind Eng Chem 28:28-31

Parsons JR, Storms MCM (1989) Biodegradation of chlorinated dibenzo-pdioxins in batch and continuous cultures of strain JB1. Chemosphere 19:1297-1308

Parsons JR, de Bruijne JA, Weiland AR (1998) Biodegradation pathway of 2-chlorodibenzo-pdioxins and 2-chlorodibenzofuran in the biphenylutilising strain JBI. Chemosphere 37:1915-1922

Peng P, Haiyan Y, Ruibao J, Li L (2013) Biodegradation of dioxin by a newly isolated Rhodococcus sp. with the involvement of self-transmissible plasmids. Appl Microbiol Biotechnol 97:5585-5595

Roggo C, Coronado E, Moreno-Forero SK, Harshman K, Weber J, van der Meer JR (2013) Genome-wide transposon insertion scanning of environmental survival functions in the polycyclic aromatic hydrocarbon degrading bacterium Sphingomonas wittichii RW1. Environ Microbiol 15:2681-2695

Rose M (2014) Environmental contaminants: Dioxins, furans, and dioxin-like polychlorinated biphenyls A2. In: Motarjemi Y (ed) Encyclopedia of food safety. Academic Press, Waltham, pp 315-322

Sahni SK, Jaiswal PK, Kaushik P, Thakur IS (2011) Characterization of alkalotolerant bacterial community by 165 rDNA-based denaturing gradient gel electrophoresis method for degradation of dibenzofuran in soil microcosm. Int Biodeter Biodegr 65:1073-1080

Sato S, Nam JW, Kasuga K, Nojiri H, Yamane H, Omori T (1997) Identification and characterization of genes encoding carbazole 1,9a-dioxygenase in Pseudomonas sp. strain CA10. J Bacteriol 179:4850-4858

Schmidt A, Rothe B, Altenbuchner J, Ludwig W, Engesser KH (1997) Characterization of three distinct extradiol dioxygenases involved in mineralization of dibenzofuran by Terrabacter sp strain DPO360. J Bacteriol 179:53-62

Schreiner G, Wiedmann T, Schimmel H, Ballschmiter K (1997) Influence of the substitution pattern on the microbial degradation of mono-to tetrachlorinated dibenzo-p-dioxins and dibenzofurans. Chemosphere 34:1315-1331

Seeger M, Camara B, Hofer B (2001) Dehalogenation, denitration, dehydroxylation, and angular attack on substituted biphenyls and related compounds by a biphenyl dioxygenase. J Bacteriol 183(12):3548-3555

Selifonnov SA, Slepenkin AV, Adanin VM, Yu Nefedova M, Starovoitov II (1992) Oxidation of dibenzofuran by Pseudomonas harboring plasmids for naphthalene degradation. Microbiol 60:714-717

Seo JS, Keum YS, Li QX (2009) Bacterial degradation of aromatic compounds. Int J Environ Res Public Health 6:278-309

Squadrone S, Brizio P, Nespoli R, Stella C, Abete MC (2015) Human dietary exposure and levels of polychlorinated dibenzo-p-dioxins (PCDDs), polychlorinated dibenzofurans (PCDFs), dioxin-like polychlorinated biphenyls (DL-PCBs) and non-dioxin-like polychlorinated biphenyls (NDL-PCBs) in free-range eggs close to a secondary aluminum smelter, Northern Italy. Environ Pollut 206:429-436

Stope M, Becher D, Hammer E, Schauer F (2002) Cometabolic ring fission of dibenzofuran by Gram-negative and Gram-positive biphenyl-utilizing bacteria. Appl Microbiol Biotechnol 59:62-67

Sukda P, Gouda N, Ito E, Miyauchi K, Masai E, Fukuda M (2009) Characterization of a transcriptional regulatory gene involved in dibenzofuran degradation by Nocardioides sp. strain DF412. Biosci Biotechnol Biochem 73:508-516

Suzuki S, Hiraishi A (2007) Novosphingobium naphthalenivorans sp. nov., a naphthalene-degrading bacterium isolated from polychlorinateddioxin-contaminated environments. J Gen Appl Microbiol 53:221-228

Suzuki YM, Nakamura Y, Otsuka Y, Suzuki N, Ohyama K, Kawakami T et al (2016) 2,3,7,8-tetrachlorodibenzo-p-dioxin (TCDD) degradation by the thermophilic Geobacillus sp. UZO 3. J Environ Biotechnol 2:105-108

Suzuki Y, Nakamura M, Otsuka Y, Suzuki N, Ohyama K, Kawakami T, SatoIzawa K, Navarro RR, Hishiyama S, Inoue K, Kameyama T, Takahashi A, Katayama Y (2018) Cloning and sequencing of the gene encoding the enzyme for the reductive cleavage of diaryl ether bonds of 2,3,7,8-tetrachlorodibenzo-p-dioxin in Geobacillus thermodenitrificans UZO 3. J Biosci Bioeng. https://doi.org/10.1016/j.jbiosc.2018.04.013

Thanh LTH, Thi TVN, Shintani M, Moriuchi R, Dohra H, Loc NH, Kimbara K (2019) Isolation and characterization of a moderate thermophilic Paenibacillus 
naphthalenovorans strain 4B1 capable of degrading dibenzofuran from dioxin-contaminated soil in Vietnam. J Biosci Bioeng 128:571-577

Townsend DI (1983) Change of isomer ratio and fate of polychlorinated- $p$ -dioxins in the environment. Chemosphere 12:637-643

Tu YT, Liu JK, Lin WC, Lin JL, Kao CM (2014) Enhanced anaerobic biodegradation of OCDD-contaminated soils by Pseudomonas mendocina NSYSU: microcosm, pilot-scale, and gene studies. J Hazard Mater 278:433-443

Tue NM, Goto A, Takahashi S, Itai T, Asante KA, Kunisue T, Tanabe S (2016) Release of chlorinated, brominated and mixed halogenated dioxinrelated compounds to soils from open burning of e-waste in Agbogbloshie (Accra, Ghana). J Hazard Mater 302:151-157

Vidali M (2001) Bioremeiation. An overview. Pure Appl Chem 73(7):1 163-1172

Wang Y, Oyaizu H (2011) Enhanced remediation of dioxins-spiked soil by a plant-microbe system using a dibenzofuran-degrading Comamonas sp. and Trifoliumrepens L. Chemosphere 85:1109-1114

Wang Y, Yamazoe A, Suzuki S, Liu CT, Aono T, Oyaizu H (2004) Isolation and characterization of dibenzofuran-degrading Comamonas sp. strains isolated from white clover roots. CurrMicrobiol 49:288-294

Wang C, Chen Q, Wang R, Shi C, Yan X, He J, Hong Q, Li S (2014) A novel angular dioxygenase gene cluster encoding 3-phenoxybenzoate $1^{\prime}, 2^{\prime}$-dioxygenase in Sphingobium wenxiniae JZ-1. Appl Environ Microbiol 80(13):3811-3818

Weber R, Tysklind M, Gaus C (2008) Dioxin—contemporary and future challenges of historical legacies. Environ Sci Pollut Res 15:96-100

Wilkes H, Wittich RM, Timmis KN, Fortnagel P, Francke W (1996) Degradation of chlorinated dibenzofurans and dibenzo-p-dioxins by Sphingomonas sp. strain RW1. Appl Environ Microbiol 62:367-371
Wittich RM (1998) Degradation of dioxin-like compounds by microorganisms. Appl Microbiol Biotechnol 49:489-499

Wittich RM, Wilkes H, Sinnwell V, Francke W, Fortnagel P (1992) Metabolism of dibenzo-p-dioxin by Sphingomonas sp. strain RW1. Appl Environ Microbiol 58:1005-1010

Wittich RM, Strömpl C, Moore ERB, Blasco R, Timmis KN (1999) Interaction of Sphingomonas and Pseudomonas strains in the degradation of chlorinated dibenzofurans. J Ind Microbiol Biotechnol 23:353-358

Wu JH, Chen WY, Kuo HC, Li YM (2019) Redox fluctuations shape the soil microbiome in the hypoxic bioremediation of octachlorinated dibenzodioxin- and dibenzofurancontaminated soil. Environ Pollut 248:506-515

Xu P, Yu B, Li FL, Cai XF, Ma CQ (2006) Microbial degradation of sulfur, nitrogen and oxygen heterocycles. Trends Microbiol 14:398-405

Yamazoe A, Yagi O, Oyaizu H (2004) Degradation of polycyclic aromatic hydrocarbons by a newly isolated dibenzofuran-utilizing Janibacter sp. strain YY-1. Appl Microbiol Biotechnol 65:211-221

Yoshida N, Takahashi N, Hiraishi A (2005) Phylogenetic characterization of a polychlorinated dioxin dechlorinating microbial community by use of microcosm studies. Appl Environ Microbiol 71:4325-4334

\section{Publisher's Note}

Springer Nature remains neutral with regard to jurisdictional claims in published maps and institutional affiliations.

\section{Submit your manuscript to a SpringerOpen ${ }^{\odot}$ journal and benefit from:}

- Convenient online submission

- Rigorous peer review

- Open access: articles freely available online

- High visibility within the field

- Retaining the copyright to your article

Submit your next manuscript at $\mathbf{s p r i n g e r o p e n . c o m ~}$ 